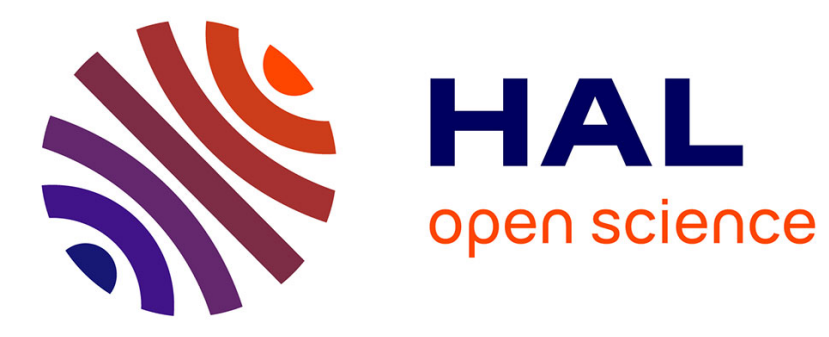

\title{
Wind effects on snow cover in Pascua-Lama, Dry Andes of Chile
}

Simon Gascoin, Stefaan Lhermitte, Christophe Kinnard, Kirsten Borstel, Glen E. Liston

\section{- To cite this version:}

Simon Gascoin, Stefaan Lhermitte, Christophe Kinnard, Kirsten Borstel, Glen E. Liston. Wind effects on snow cover in Pascua-Lama, Dry Andes of Chile. Advances in Water Resources, 2013, 55, pp.25-39. 10.1016/j.advwatres.2012.11.013 . hal-00756902

\section{HAL Id: hal-00756902 https://hal.science/hal-00756902}

Submitted on 23 Nov 2012

HAL is a multi-disciplinary open access archive for the deposit and dissemination of scientific research documents, whether they are published or not. The documents may come from teaching and research institutions in France or abroad, or from public or private research centers.
L'archive ouverte pluridisciplinaire HAL, est destinée au dépôt et à la diffusion de documents scientifiques de niveau recherche, publiés ou non, émanant des établissements d'enseignement et de recherche français ou étrangers, des laboratoires publics ou privés. 


\title{
Wind effects on snow cover in Pascua-Lama, Dry Andes of Chile
}

\author{
Simon Gascoin ${ }^{\mathrm{a}, \mathrm{b}}$, Stefaan Lhermitte ${ }^{\mathrm{c}, \mathrm{b}}$, Christophe Kinnard ${ }^{\mathrm{b}}$, Kirsten \\ Borstel $^{\mathrm{b}}$, Glen E. Liston ${ }^{\mathrm{d}}$ \\ ${ }^{a}$ Centre d'Études Spatiales de la Biosphère (CESBIO), Toulouse, France \\ ${ }^{b}$ Centro de Estudios Avanzados en Zonas Áridas (CEAZA), La Serena, Chile \\ ${ }^{c}$ Royal Netherlands Meteorological Institute (KNMI), De Bilt, The Netherlands \\ ${ }^{d}$ Cooperative Institute for Research in the Atmosphere (CIRA), Colorado State \\ University, Fort Collins, USA
}

\section{Abstract}

We present the first application of a distributed snow model (SnowModel) in the instrumented site of Pascua-Lama in the Dry Andes (2600-5630 m above sea level, $29^{\circ} \mathrm{S}$ ). A model experiment was performed to assess the effect of wind on the snow cover patterns. A particular objective was to evaluate the role of blowing snow on the glacier formation. The model was run using the data from 11 weather stations over a complete snow season. First, a cross-validation of the meteorological variables interpolation model (MicroMet submodel) was performed to evaluate the performance of the simulated meteorological forcing. Secondly, two SnowModel simulations were set up: one without and the other with the wind transport submodel (SnowTran-3D). Results from both simulations were compared with in situ snow depth measurements and remotely sensed snow cover data. The inclusion of SnowTran-3D does not change the fact that the model is unable to capture the small-scale snow depth spatial variability (as captured by in situ snow depth sensors). However, remote sensing data (MODIS daily 
snow product) indicate that at broader scales the wind module produced an improved representation of the snow distribution near the glaciers (2-D correlation coefficient increased from $R=0.04$ to $R=0.27)$. The model outputs show that a key process is the sublimation of blowing snow, which amounts to $18 \%$ of the total ablation over the whole study area, with a high spatial variability. The effect of snow drift is more visible on the glaciers, where wind-transported snow accumulates preferentially. Net deposition occurred for $43 \%$ of the glacier grid points, whereas it is only $23 \%$ of non-glacier grid points located above the minimum glacier altitude $(4475 \mathrm{~m})$.

Keywords: snow, glacier, wind, sublimation, Andes, MODIS, SnowModel, snowdrift, blowing snow sublimation, semiarid mountain

\section{Introduction}

The Dry Andes region spans from $20^{\circ} \mathrm{S}$ to $35^{\circ} \mathrm{S}$ and covers the aridest 3 part of the Andes Cordillera [1]. Due to the low precipitation and high solar 4 radiation, glacier cover is small in the Dry Andes in comparison with the 5 tropical Andes in the north or the Andes of central Chile in the south [2]. 6 In the semi-arid lowlands of Chile, the annual precipitation is not sufficient 7 for sustaining the agriculture sector, which provides most of the regional employment. The cultivators rely on snowmelt, and glacier runoff to a lesser extent, from the high-altitude area for irrigating the fields during the growing season [3]. The mining industry is the other main economic activity in this mineral-rich region. The scarcity of the water resource is the cause of a persistent conflict between both sectors [4]. In 2005 a controversy about the Pascua-Lama mine project, which initially implied the displacement of 
glacial ice, revealed that the local population was particularly concerned by the fate of the glaciers in the Dry Andes both in Chile and Argentina [5].

In the Dry Andes, two particular processes are known to be critical for the study of the cryosphere. First, sublimation is a major component of the snow and ice mass balance. Low air humidity, high solar radiation and strong winds result in large sublimation rates. For example, sublimation was estimated to represent $89 \%$ (327 mm w.e.) of the mean annual ablation near the summit of the Tapado glacier between 1962 and 1999 (5536 m a.s.l.) [6]. At the same location Ginot et al. [7] observed daily sublimation rate of 1.9 $\mathrm{mm}$ w.e from lysimeter measurements. In Pascua-Lama further lysimeter measurements revealed that sublimation rates could exceed $3 \mathrm{~mm} / \mathrm{d}[8]$. Another key aspect of the Dry Andes cryosphere is the effect of the wind on the snow distribution. This aspect was much less documented but pointed out by Ginot et al. [6] to explain the presence of a glacier on the Cerro Tapado, while higher surrounding mountains are glacier-free. Rabatel et al. [9] also emphasized the effect of wind on the spatial distribution of glaciers in the Pascua-Lama area, in addition to the shading effect. Based on the hydrological balance equation, Gascoin et al. [8] found that the contribution of the glacierized fraction of the catchment area to the mean annual streamflow was greater than the contribution from the non-glacierized fraction and suggested that this was mainly due to enhanced meltwater production from negative net glacier mass-balance, while deposition of wind-transported snow from the non-glacier area to the glacier surface increased the winter balance of the glaciers. However, no study has brought conclusive evidence that wind contributes to glacier formation in the Dry Andes. Yet, there is growing 
evidence that wind-related processes have a strong impact on glacier accumulation in other mountain ranges. Based on a similar hydrological balance analysis in the Paznaun basin (Austrian Alps), Kuhn [10] introduced an empirical "redistribution factor" in order to account for the fact that "glaciers receive twice as much precipitation as the basin average". This observation was attributed to the combined effects of wind transport of snow from the ice-free areas, precipitation variability and avalanches. The specific effect of wind on glacier accumulation was further characterized at the glacier scale by Machguth et al. [11], Mott et al. [12], Bernhardt et al. [13], Dadic et al. [14], Carturan et al. [15] in the European Alps, and Purdie et al. [16] in the Southern Alps of New-Zealand. The physical processes governing the wind influence on snow accumulation were recently summarized into two main processes by Dadic et al. [14], based on previous work by Lehning et al. [17]: (i) the transport of already-deposited snow (often referred to as snow drift), which includes suspension and saltation processes; (ii) the preferential deposition of precipitation due to topographic-induced wind field perturbation during a snow storm.

Yet the wind does not only play an important role in shaping the snow accumulation on glaciers. Apart from the process of snow erosion due to wind shear stress on the surface, the local wind field is also a critical factor of the snow ablation since it determines the turbulent exchanges of heat and moisture between the snow surface and the atmosphere, especially over small ice bodies and snow patches $[18,19]$. Hence the wind is an important driver of the static-surface sublimation and melting [20]. Furthermore, wind transport of suspended snow increases sublimation and thus ablation [21, 22, 23]. To 
our knowledge, a full assessment of all these processes for glaciers over a season or longer has not yet been achieved yet.

There are relatively fewer studies dealing with the effects of wind on snow cover in semi-arid mountains than in temperate climate mountains. Marks and Winstral [24] emphasized the importance of accounting for spatiallyvariable energy inputs and snow deposition patterns to model snowmelt in a semi-arid mountain catchment of southern Idaho. In the same area, Winstral and Marks [25] used terrain-based parameters to model the distributed wind speeds and accumulation rates. The snow model forced with these fields successfully simulated the observed snow distribution and melt, while the same model forced with spatially constant wind and accumulation overestimated peak snowmelt.

In this paper, we have considered only the wind effects on snow cover due to snow drift (suspension and saltation) and blowing snow sublimation in order to understand the effects of wind on snow cover and glacier formation in the Dry Andes. The wind effect on static-surface snow sublimation was not directly investigated as it is not related to snow transport. For that purpose we applied a distributed snow model that accounts for snow transport by the wind (SnowModel, [26]) in the Pascua-Lama area. SnowModel is a distributed mass and energy balance model, which allows the interpolation of the meteorological forcing based on in situ data (weather stations). The wind speeds and directions are modified according to the topography using terrain-based parameters [27]. A similar application of SnowModel was presented by Bernhardt et al. [13] in the Bavarian Alps. The authors found that the wind fields generated by the MM5 atmospheric model were more 
reliable than the standard interpolated wind fields generated by SnowModel. However, the MM5-generated wind speeds and directions were still corrected with the same terrain-based parameterizations as in SnowModel, and yielded a good representation of the snow patterns. The model was used to estimate the amount of transported snow from the surrounding areas to the glacier [13].

Based on these insights, and because it is the first application of a distributed snow model in the semi-arid Andes that we are aware of, this study focused on the model assessment based on multiple data sources. First, the model spatial interpolation scheme was tested for all the input meteorological variables. Secondly, the model was run with and without the wind transport module to analyze the effects of wind on the snow mass balance. Finally, both simulations were compared to in situ observations and remote sensing data.

\section{Study area}

The Pascua-Lama area is located in the high Andes of the Chilean Atacama Region near the border of Argentina (29.3 S; 70.1 W) (Fig. 1). The elevation ranges between $2600 \mathrm{~m}$ and $5630 \mathrm{~m}$ a.s.l. Vegetation cover is extremely sparse and virtually absent above $3800-\mathrm{m}$. The landscape is dominated by large and steep granitic outcrops. The study area comprises various glaciers (including glaciarets, i.e. small ice bodies with little or no sign of flow) occurring on the southern slopes of the highest peaks between 4780 and $5485 \mathrm{~m}$ a.s.l $[2,9]$. As north-westerly winds dominate, southern slopes correspond to the leeward slopes. The snow cover and glaciers in the study 
area are characterized by the formation of penitents, a typical feature of the Dry Andes which derive from the sublimation process [1]. These columnar shapes of snow or ice can frequently exceed $2 \mathrm{~m}$ in height, especially in windsheltered spots. They grow as a result of a differential ablation rate between the crest and the base of the penitents [28]. The ablation rate is higher at the base of a penitent, because the humidity and radiation conditions are more favorable to melting, while the crest lose mass predominantly by sublimation. However, the initiating processes remain unclear [29], which helps explain why they are not represented in any snow evolution model. In this study we did not account for the formation of the penitents. The study area usually gets completely snow covered in winter. Nonetheless, the snowfall interannual variability is pronounced as the region is under the influence of the El Nino Southern Oscillation (ENSO). The last ENSO episode affecting the study area was in winter 2002 and caused heavy snowfalls [8]. The environmental impact assessment process for the Pascua-Lama mining project decided by the Chilean Government [30] involves the monitoring of various environmental variables related to snow, glaciers and atmosphere. This context explains the wealth of meteorological data that were available for this study (11 weather stations). As of today it is one of the best documented sites for the study of the cryosphere in the Dry Andes [9, 8].

\section{Method}

\subsection{Model description}

SnowModel is a spatially-distributed snow model adapted for the study of snow redistribution by wind $[26,31]$. It has already been applied in a va- 
riety of alpine (Rocky Mountains, [32]; European Alps, [13]) and arctic landscapes [33], but never in the Andes. SnowModel comprises four submodels: MicroMet, EnBal, SnowPack and SnowTran-3D. MicroMet performs spatial and temporal interpolation to produce the spatially distributed meteorological fields required to run the other submodels [34]. EnBal is a standard energy balance snow model $[35,36]$ which simulates energy and water fluxes from MicroMet outputs. SnowPack is a snow depth and snow density evolution model [35]. SnowTran-3D simulates the evolution of snow depth due to wind blowing snow $[21,26,31]$. Snow transport by avalanches is not represented. The model works by coupling the four submodels at the forcing data time step (typically 1 hour), effectively resolving the mass balance of the snowpack at each time step. A complete description of the model structure and a summary of the previous applications can be found in Liston and Elder [26]. Here we focus on blowing snow sublimation and snow transport by wind, which are expected to be key processes of the snow mass balance. The MicroMet submodel interpolates the weather stations measurements to a two-dimensional grid based on the Barnes objective function [37]. The Barnes interpolator does not account directly for elevation. Prior to the interpolation, the data are converted to sea-level surface data using a linear lapse rate. The interpolated grid is taken back to the actual elevation using the same lapse rates. The wind speed and direction are interpolated using this method, then the gridded values are modified according to topographic slope and curvature relationships [31]. A static-surface sublimation term is simulated by EnBal as a result of the energy balance equation (turbulent flux of latent heat from the surface). Additionally, SnowTran-3D simulates the 
sublimation of windborne snow during the saltation and turbulent suspension processes [31].

The latest available version of SnowModel was used for this study (last update on 08-Sep-2011). The original Walcek [38] parameterizations for cloud cover fraction in MicroMet [34] was modified, because preliminary analyses indicated underestimation of the simulated fraction, resulting in an overestimation of incoming shortwave and underestimation of incoming longwave (not shown here). This was corrected by rescaling the obtained cloud cover fraction using Walcek's parametrization to the 0-1 cloud cover interval, based on the cloud cover data derived from the analysis of shortwave radiation measurements in the study area [39].

\subsection{Model setup}

The modeling domain is shown in Fig. 1. The computational grid has the same resolution as the digital elevation model, which was extracted from the Shuttle Radar Topography Mission 90 m spatial resolution data version 2.1 [40]. While a main objective of the study is the analysis of the snow mass balance over the glaciers, we chose to simulate the snow cover over a larger area, for two reasons (i) it enables a better model assessment since most of the snow depth measurements sites are off-glacier and a large domain allows the comparison with satellite observations; (ii) it enables to compare the snow mass balance over glacier with glacier-free areas. Most of the model parameters were set to their default value (Tab. 1). The threshold surface shear velocity was assumed to be constant during the simulation $(0.25 \mathrm{~m} / \mathrm{s})$. The snow subgrid redistribution was not activated [41]. The curvature length scale was estimated based on the DEM to be $500 \mathrm{~m}$, i.e. approximately 
one-half the wavelength of the topographic features within the domain [31]. SnowModel was run for the period 1-May-2008 to 31-November-2008, which corresponds to a complete snow season. At the beginning of the simulation the snowpack was set to zero. Meteorological data from 11 AWS were used to force MicroMet (Tab. 2, Fig. 2). A summary of the available meteorological forcing data is given in Tab. 2. The longwave radiation sensors were operated only from 09-Oct-2008 at Toro 1 and Guanaco AWS (75\% missing values). As a result, there are few longwave data for the simulation period to be assimilated by MicroMet. Snow depth was recorded every hour at six weather stations using Campbell Scientific SR50 and SR50A acoustic sensors (Tab. 2). Among these six stations, three are located on a glacier (Guanaco, Toro 1, and Ortigas), while the three others are located on bare ground (La Olla, El Toro, Tres Quebradas).

Since vegetation is essentially absent in the model area, the land cover type was set to bare ground everywhere except for the glaciated areas where we used the "permanent snow/glacier" class defined in SnowModel.

There are precipitation gauges in the study area but the data were found to be unusable due to inappropriate operation and maintenance. Therefore precipitation was estimated from snow depth measurements. First, we used as a reference the manual snow depth measurements which are made at the mine base camp ("Campamento", Fig. 1). At this site, during each precipitation event, a meteorologist typically surveyed the depth of accumulated snow on the ground every two hours. These data were interpolated to a 1 hour time step. In addition, we used the continuous hourly snow depth measurements from six meteorological stations equipped with acoustic 
snow gauges. These data were filtered to extract only positive snow depth increases during the days that precipitation was observed at Campamento. We assumed that snow settling during the snowfall can be negelected at this hourly timestep. The filter was applied to the days of Campamento precipitation (rather than the hours) to allow for some delay in the precipitation occurrence between Campamento and the other sites. The resulting hourly snowfall records (seven series including Campamento) were then converted from snow depth to water equivalent using the empirical formula of Anderson [42] for new snow density $(\rho)$ :

$$
\rho=50+1.7\left(T_{w}-258.16\right)^{1.5}
$$

where $T_{w}$ is the wet-bulb temperature. $T_{w}$ was calculated following Liston and Hall [35], i.e. using the formula given by Rogers [43]:

$$
T_{w}=T_{a}+\left(e_{a}-e_{s}\left(T_{w}\right)\right) \frac{0.622 L_{v}}{P_{a} C_{p}}
$$

where $T_{a}$ is the surface-air temperature, $e_{a}$ is the atmospheric vapor pressure, $e_{s}\left(T_{w}\right)$ is the vapor pressure of the surface at wet-bulb temperature, $L_{v}$ is the latent heat of sublimation, $P_{a}$ is the atmospheric pressure at the surface and $C_{p}$ is the specific heat of air. The atmospheric vapor pressure was computed with the coefficients for saturation vapor pressure over ice [44]:

$$
e_{a}=A h \exp \frac{B\left(T_{a}-T_{f}\right)}{C+\left(T_{a}-T_{f}\right)}
$$

with $A=611.21 \mathrm{~Pa} ; B=22.452 ; C=272.55^{\circ} \mathrm{C}$, and where $h$ is the relative humidity and $T_{f}$ is the freezing temperature. The vapor pressure of the surface at wet-bulb temperature is given by [45]:

$$
\log _{10}\left(e_{s}\left(T_{w}\right)\right)=11.40-2353 / T_{w}
$$


The wet bulb temperature was obtained by iteration until a $0.01 \mathrm{~K}$ convergence criteria was reached.

These precipitation data were used as input to MicroMet. The resulting precipitation rates averaged per event over the study area are given in Tab. 3 .

To account for the variations of air temperature and relative humidity with elevation, SnowModel uses standard values of air temperature and dewpoint temperature monthly lapse rates. However, SnowModel also allows the user to specify these lapse rates to better capture the local meteorological conditions. For this study we computed the lapse rates using data from the 11 meteorological stations (Tab. 2). For every month between May and November 2008 the regression slope between the monthly air temperature and the station elevation was determined using the Matlab robustfit default algorithm [46] (iteratively reweighted least squares with a bisquare weighting function). This algorithm was chosen because it decreases the influence of outliers on the regression. The same procedure was applied to the dewpoint temperature (only 10 stations). The lapse rates were computed for the dewpoint temperature because the relative humidity is a non linear function of elevation. The lapse rates obtained for the study area are shown in Tab. 4.

\subsection{Model experiments}

First, the MicroMet submodel performance was assessed using a leaveone-out cross-validation approach. For a given meteorological variable, each AWS (the target) was successively removed from the calibration data set. This reduced data set was used to predict the left-out variable at the target location using MicroMet. This procedure was repeated for each AWS using all the available data over the simulation period (Tab. 2). The accuracies of 
the predicted variables were analyzed using the coefficient of determination $\left(R^{2}\right)$ and the bias $(B)$ calculated from hourly data. For the wind direction, only the bias was calculated, which corresponds to the mean of the angular difference between the simulated and observed wind direction at each timestep.

Secondly, we carried out two simulations with SnowModel: for the first simulation SnowTran-3D was disabled (labeled without SnowTran), while it was activated for the second one (labeled with SnowTran). Otherwise, both simulations had the same input data and parameters. We used the studyarea lapse rates. The results were compared to snow depth measurements from AWS and to snow cover area from MODIS data.

\subsection{Simulated snow cover area}

Snow cover area (SCA, i.e. the area of the modeling domain which is covered by snow) is not a standard output of SnowModel. Various methods exist to convert the simulated snow depth or snow water equivalent to a snow covered fraction of a model element [47]. However, these methods, such as the depletion curve parameterization [48] are largely dependent upon the model cell size, topography and land cover and must be adapted empirically to the modeling domain provided that sufficient field observations are available. An accurate SCA-SWE transformation is required for assimilating SCA data into a hydrological model. Here we only aimed at discriminating two simulations using the MODIS snow cover product, which allowed more flexibility. We opted for a SWE-SCA conversion that matches the reported detection accuracy of MODIS snow product. Klein and Barnett [49] reported that the majority of misdetections occurred at snow depths of less than 40 
mm. Hence, a grid cell was flagged as snow-covered if the simulated SWE was larger than $10 \mathrm{~mm}$ w.e. on the same day (i.e. approximately 20 to $100 \mathrm{~mm}$ of snow depth). The sensitivity of the computed snow cover area to this threshold was assessed using two additional SWE thresholds (4 mm w.e. and $20 \mathrm{~mm}$ w.e.). These values correspond to the conversion of $40 \mathrm{~mm}$ snow depth to SWE under the typical range of observed snow densities $\left(100 \mathrm{~kg} / \mathrm{m}^{3}\right.$ and $500 \mathrm{~kg} / \mathrm{m}^{3}$ ). To perform a pixel-to-pixel comparison between MODIS and SnowModel, the SCA maps were resized to the MODIS spatial resolution using a bilinear smoothing method (in this case the SWE threshold was set to $10 \mathrm{~mm}$ w.e.).

\subsection{Validation data}

\subsubsection{Snow depth}

The acoustic snow gauge records were partly used to generate the precipitation forcing (Sect. 3.2.1.). However, only the positive snow depth deviations recorded by the snow gauges during the precipitation events measured at Campamento were used to calculate the precipitation, i.e. a few values among the whole records, so that the snow depth series from these gauges can still be used to validate the temporal evolution of the snowpack at these sites. The data from the stations on ground were filtered to remove the noise around the reference height (i.e. snow depth was set to zero when the measured distance oscillates around the sensor-ground distance). This processing was not performed for the glacier station data as the reference height may fluctuate naturally due to the compaction or melting of the underlying glacier layers. 


\subsubsection{Snow cover area}

We used the MODIS/Terra daily snow cover product MOD10A version 5 [50], which provides binary snow cover data (snow or no snow) on a $500 \mathrm{~m}$ resolution grid and a cloud mask on a daily basis since 2000. The MOD10A v5 product and previous versions were validated using ground snow measurements in various mountainous regions [51], including the semi-arid Southern Rocky Mountains [49], which present some analogous climatic and topographic conditions as in the north-central Andes. One of the main issues related to the MODIS data exploitation for model assessment is the cloud obstruction. Nebulosity is low in the Norte Chico so that cloud cover is expected not to be prohibitive for model validation even in winter and spring. In the study area, only $27 \%$ of the data are marked as cloud over the model simulation period (214 days). Nonetheless cloud obstruction must be accounted for to estimate the snow coverage over the region of interest. For this study we generated a cloud-free snow mask for every date by interpolating the MOD10A1 product based on the nearest-neighbors method along the time dimension (temporal filter, [52]). In the original data, the mean maximal duration of successive cloudy days is 9.5 days (standard deviation 3.2 days). This means that in average for each time series the interpolation algorithm can fill up to 5 days of cloud-flagged data with the previous or the next non-obscured available data. We found that the cloud obstruction probability is much higher over the ore body (up to 38 successive days flagged as cloud obscured), suggesting that the cloud detection algorithm failed in this area. This might be related to the bright aspect of this weathered portion of the igneous bedrock, forming a highly reflective surface in the visible spec- 
tra. Otherwise the cloud mask appeared qualitatively reliable. The cloud-free snow maps were then used to compute the snow cover fraction over the whole domain $\left(1043 \mathrm{~km}^{2}\right.$, Fig. 1). Because of the possible persistence of cloud obstruction over several day, the interpolated data must be considered with caution. Hence we represented the cloud coverage in addition to the snow coverage derived from MOD10A1 to avoid misinterpretation of the results. The MODIS snow product was used in two ways (i) as a temporal validation (without the spatial component) and (ii) as a seasonal and spatial validation (without the temporal component).

\section{Results}

\subsection{MicroMet validation}

The results of the cross-validation (Tab. 5) indicate that most variables are well simulated by MicroMet. The coefficients of determination $\left(R^{2}\right)$ computed for each station range between 0.83 and 0.98 for air temperature and between 0.58 and 0.93 for the relative humidity. The biases are relatively low for these variables (temperature: mean bias: $-0.15^{\circ} \mathrm{C}$, standard deviation: $0.66^{\circ} \mathrm{C}$; humidity: mean bias $-0.37 \%$, standard deviation: $\left.4.7 \%\right)$. High values of the coefficient of determination mostly result from the good correlation of the diurnal cycles. Low biases, however, are due to the inclusion of the observed lapse rates in MicroMet, which allowed the reduction of large discrepancies in temperature and humidity if the standard lapse rates were used (not shown here).

As expected, the accuracy of MicroMet is much lower for the wind variables. In particular, the wind speeds are generally underestimated by Mi- 
croMet by about $1 \mathrm{~m} . \mathrm{s}^{-1}$ up to $4 \mathrm{~m} \cdot \mathrm{s}^{-1}$ at Guanaco (Tab. 5). The biases in wind direction approximately range within $-40^{\circ}$ and $40^{\circ}$, except for Tres Quebradas where a large angular discrepancy is observed (Fig. 2). The largest discrepancies are observed in the valley stations (Tres Quebradas and La Olla), which are protected from the general wind flow, and where the finescale topography and the diurnal cycle (slope-wind circulation, at La Olla) are essential in determining the wind speed. On the other hand, the wind field is relatively consistent with the data at the high-elevation stations as it reproduces the dominant north-western flow (Fig. 2). Based on these results, we conclude here that the MicroMet output are realistic enough to test with SnowTran-3D the effects of wind on snow cover in the high altitude areas, which are more prone to the dominant wind field.

Comparison of the observed and modeled incoming shortwave radiation on a flat surface shows high correlation coefficients and relatively low biases. Moreover, these biases are mainly the result of systematic offsets at the beginning and end of the diurnal cycle (not shown here), which can be caused by small timing differences (e.g. clock timing offset) or small leveling errors of shortwave sensors. However, as these biases are relatively low in comparison with the incoming shortwave radiation, the high correlation coefficients reflect the robustness of Micromet used in combination with shortwave assimilation to represent the observed incoming shortwave radiation. Conclusions on the accuracy of modeled incoming longwave radiation are more difficult to draw as we only have incoming longwave radiation observations for two stations since October (Tab. 2). Nevertheless, longwave data comparisons yields high $R^{2}$ values and low biases. Moreover, given the low nebulosity of the area 
and consistent longwave time series before and after assimilation in October, we believe Micromet accurately represents the incoming longwave radiation before October.

\subsection{SnowTran-3D effect}

\subsubsection{Model mass budget}

Fig. 3 shows that the activation of SnowTran-3D has an important impact on the temporal distribution of the monthly water budget for the whole domain. Sublimation of windborne snow increased by $17 \mathrm{~mm}$ w.e. the mass loss in winter (between June and August). As a result, less snow is available for melting in the spring. However, the static-surface sublimation computed in the EnBal submodel remains the main ablation component of the total snow ablation in both simulations, which is consistent with the findings of [23] in the Swiss Alps. The total contribution of the sublimation (static-surface and blowing snow sublimation) to the total ablation was only marginally modified by the activation of SnowTran-3D (73\% without SnowTran-3D vs. $71 \%$ with SnowTran-3D). The wind transported snow term corresponds to the mean snow loss by saltation and suspension drifted outside of the model domain and accounts for only $6 \%$ of the total mass loss (12 mm w.e.). However, the amount of transported snow is highly variable within the model domain. Some grid cells located on the south-eastern slopes of the highest crest (leeward side) have gained up to $200 \mathrm{~mm}$ w.e. at the end of the simulation period (Fig. 4). In average $30 \%$ of the grid cells have gained snow due to wind transport. The resulting distribution of the mean SWE is skewed to the higher SWE depths (Fig. 6), showing that SnowTran-3D tends to "concentrate" the snow distribution by depleting the snowpack from the majority 
of the grid cells to accumulate large amounts of snow on a few grid cells. As shown in Fig. 7, both simulations yield different spatial distribution of the mean SWE depth, in particular in the eastern half of the domain, where the highest peaks and all the glaciers are found (see Sect. 4.2.4).

\subsubsection{Comparison with snow depth observations}

The pointwise comparison with the snow depth measurements yields rather poor results (Fig. 8). While the simulated snow depths at Tres Quebradas site is satisfactory, large discrepancies are observed between the simulation and the measurements at the other sites. The model underestimated the snow ablation at Guanaco and La Olla sites, but overestimated it on glaciers Ortigas and Toro 1. Given the high spatial heterogeneity of the glacier surface in this area (e.g. formation of snow penitents), such a discrepancy can be expected for the glaciers stations. The model results for the ground stations El Toro and Tres Quebradas are in better agreement with observations. At El Toro site, a closer analysis reveals that the precipitation input in May and June caused an overestimation of the initial accumulated snow depth, but the snowpack ablation rate is actually well represented, as in Tres Quebradas. However, the model failed to represent the extremely fugitive snowpack observed at La Olla. La Olla weather station is located on an artificial platform with a steep edge facing the prevailing wind, making it vulnerable to wind erosion. As a consequence it may not be representative of the actual snow behavior in the surrounding area, i.e. at the model spatial scale $(90 \mathrm{~m})$. This is confirmed by field observations, which indicate that the snow on the weather station platform is rapidly depleted, whereas snow persists in the immediate vicinity (Fig. 9). At all sites the snow depth 
decreased more rapidly with SnowTran-3D, including the sites located on the glaciers. At this stage, the results are too uncertain to indicate whether the activation of SnowTran-3D improved the simulation.

\subsubsection{Comparison with remotely sensed snow cover}

The comparison of the snow cover area deduced from SnowModel simulations and the snow cover area computed from MOD10A1 is presented in Fig. 10. The result is encouraging given the large errors observed previously at the station scale.

- All the expected precipitation events are evident in the MOD10A1 dataset. However, a strong increase of MOD10A1 snow cover in September was not registered by in situ sensors, which suggests that this is an error of the MOD10A1 dataset. This error is probably a cloud misdetection, as this abnormal snow cover area occurred in the middle a long period of cloudy conditions.

- The effect of the SWE threshold used for snow cover mapping is smaller than the effect of SnowTran-3D on the snow cover area simulation, which indicates that the simple SWE-SCA conversion used here is sufficient for the purpose of this study.

- The activation of SnowTran-3D reduced the difference between the model and the observed SCA. In particular, the snow cover recession over the melting season (September to December) is better represented.

- Independently of SnowTran-3D, the model generally overestimated the snow cover area after a snowfall event. The simulated snow covered 
fraction of the domain reached one for four events, while MODIS data indicated that the area was never completely snow covered.

The spatially distributed snow cover probability over the modeling domain is shown in Fig. 11. The simulation results are presented at the model grid resolution $(90 \mathrm{~m})$ and compared with the MOD10A1 data $(500 \mathrm{~m})$. This comparison demonstrates that the snow cover pattern simulated with SnowTran-3D appears more consistent with the MODIS data than the one simulated without SnowTran-3D. These maps show that the temporal decrease of the snow cover area observed in Fig. 10 has essentially occurred in the area where most of the glaciers exist (but not as much on the glaciers themselves), suggesting that the wind effect is higher in this area. To provide further statistical ground to the previous results, we computed for each pixel the phi coefficient between the MOD10A1 and the simulated snow cover area daily time series (identical to the Pearsons correlation coefficient for two binary variables, in this case the absence/presence of snow at a given pixel). We focused on the glacierized region, extended to the northern and southern boundaries of the model domain, where most of SnowTran-3D effect is visible. Fig. 12 shows that more pixels have a correlation $R>0.3$ which is statistically significant at the 5\% level (P-value $<0.05)$ if SnowTran-3D is activated (155 pixels, i.e. an improvement of $8 \%$ ). In this area, the 2-D correlation coefficient between the simulated and the observed snow cover probability maps is higher with SnowTran-3D. (0.036 without SnowTran, 0.27 with SnowTran). 


\subsubsection{Wind effects on glacier vs. non-glacier areas}

The simulated transported snow pattern (Fig. 5) show that the northern halves of Guanaco and Estrecho glaciers and the western half of Ortigas glacier (i.e the three largest ice bodies in the area) have accumulated transported snow over the simulation period. The smallest ice bodies located west of Guanaco glacier and south of Ortigas glacier have high accumulation rates, as expected due to their position on the leeward side of the highest ridges.

To better characterize the effects of wind in the glacier areas, we selected the grid points located above the minimum glacier altitude (4475 m a.s.l.) and computed the net transport at the end of the simulation period for the glacier (union of all the glacier polygons) and non-glacier areas. The glacier fraction of this subdomain is $2.7 \%$. The results show that positive transport rates (net deposition) are more frequent over the glaciers (Fig. 15). Net deposition at the end of the simulation period occurs for $43 \%$ of the glacier grid points, whereas it is only $23 \%$ of non-glacier grid points.

The different components of snow mass balance were averaged over the glacier area and over the non-glacier pixels located above the minimum glacier altitude (4475 m a.s.l., Fig. 13). In both cases, the snow sublimation (staticsurface and blowing snow) is the dominant ablation term (at least $75 \%$ of the total ablation). The sublimation of blowing snow prevails over the glaciers, while static-surface is dominant over the non-glacierized area. Blowing snow sublimation also accelerates the net mass loss over the glaciers in comparison with a run without SnowTran-3D (not shown here). Snow melt remains almost negligible over the glaciers during the whole the simulation period, while it is an important ablation term in glacier-free areas during the spring 
months. But the main result is that wind transport of snow is positive on the glacier areas during the first half of the simulation period, i.e. in winter, whereas it is almost always negative in the non-glacier areas over the same period (Fig. 13). At the end of the period, the net transport values are $-6 \mathrm{~mm}$ w.e for glacier surface and $-26 \mathrm{~mm}$ w.e. for non-glaciers (Fig. 13), which shows that glaciers do not gain or lose much mass by wind transport, while outside glaciers, wind erosion is significant. Fig. 14 shows the wind speed and incoming shortwave radiation simulated by MicroMet over the glacier and non-glacier areas. The abrupt drop in the cumulated snow transport on September-02 over the glacier areas (Fig. 13) is related to the highest wind speed values modeled both over glacier and non-glacier areas (reaching $10 \mathrm{~m} / \mathrm{s}$ ), which have led to a strong but isolated erosion event. In addition, Fig. 14 shows that the glacier areas receive much less solar energy than the non-glacier areas, especially during spring and summer, which explains the lower melting rates. Hence the more positive snow mass balance modeled for glacier areas relative to glacier-free areas is predominantly explained by (i) shading, i.e, glaciers are mostly found on southerly slopes [2] and are thus more shaded from the sun; (ii) preferential deposition of wind-transported snow from glacier-free areas onto glacier surfaces during the winter period. The latter occurred mostly during winter (May-August), causing the more positive mass-balance over glacier, while sun shading is most pronounced in spring (September-November), which retards ablation of snow on glaciers compared to glacier-free areas. Hence the thicker snowpack on glaciers (115 $\mathrm{mm}$ w.e.) at the end of winter relative to glacier free terrain (77 mm w.e.) persists longer during the spring mostly due to delayed 
snowmelt and runoff.

\section{Discussion}

\subsection{Meteorological forcing}

The main assumption of this study is that the MicroMet standard interpolation scheme is sufficient to generate the wind fields over the study area. This assumption was examined based on the comparison with in situ data. In particular, the wind field appears relatively well simulated in the highest part of the domain, which is the most important for the purpose of this study. In these high-elevation areas, the local winds are mainly driven by the synoptic wind. In this context the Barnes objective function for the spatial interpolation of in situ data is well-suited. However, it is not appropriate to simulate the wind fields in the valleys, which are strongly influenced by the diurnal cycle (catabatic and anabatic flow) and the local topography. Thus, a large part of the model uncertainties probably originates from the distributed wind fields. The underestimation of the wind velocity by MicroMet may explain the lack of ablation at La Olla or Toro 1 stations. Preliminary tests indicated that the calibration of the MicroMet parameters based on the wind speed AWS data did not succeed in improving the simulated wind (curvature length scale, slope and curvature weights, Tab. 1). Thus, the wind simulation should be the focus for further applications of SnowModel or any distributed snow model in this area, e.g. by using a high-resolution weather forecast mesoscale model $[12,13,14,53,54]$.

However, another part of the model uncertainties is related to the precipitation data. The comparison with snow depth measurements showed that 
the magnitude of the precipitation was not well reproduced by the model, in spite of our efforts to incorporate the measurements of snow depth during the precipitation events. The problem is that the snow depth measurements recorded by the ultrasonic gauges during a snow storm are difficult to interpret as they combine the accumulation of precipitating snow with the deposition or removal of snow from the snowpack caused by the wind. Further work will be necessary to separate the relative contribution of these processes from ultrasonic gauge measurements, especially if the model were to be used for hydrological applications. Another option is to assimilate the snow depth measurements in the model. SnowModel includes an option to force the model towards SWE observations by precipitation and/or melt correction [41]. However, as noted before, based on field observations, it is likely that finer grid resolution might be necessary if snow depth data are to be assimilated in the Pascua-Lama area.

\subsection{Wind effects on snow cover}

We attempted to assess the effect of the SnowTran-3D submodel by comparing simulations with and without Snow Tran-3D against in situ snow depth measurements. However, the discrepancy between the data and the model is too large to conclude on the effect of SnowTran-3D at the local scale. On the other hand, the comparison with MODIS snow data suggests that the simulated snow patterns are closer to reality when SnowTran-3D is activated. The same conclusion was drawn by Prasad et al. [55] using SnowTran-3D. This conclusions should be taken with caution as the comparison between the model output and the MODIS data raises various methodological issues (e.g. SWE to SCA conversion). For this study, however, the SWE 
to SCA conversion had little impact on the conclusions (Fig. 10). Satellite imagery with higher spatial resolution (e.g. Landsat) could help to further assess the model but the temporal resolution would not allow the validation of the rapid snow cover variations. A more rapid decrease of the SCA occurs with SnowTran-3D (Fig. 10) because the combined effects of snow drift and blowing snow sublimation result in more heterogeneous snow cover patterns. (Fig. 7). Model output analyses suggest that the dominant effect of the wind transport on snow cover is the sublimation of the blowing snow, which represents $26 \%$ of the total sublimation and $18 \%$ of the total ablation. Note that the wind effect on the static-surface energy balance was simulated with EnBal but not analysed here as we focused on the wind effects on snow cover through the saltation and suspension processes (SnowTran-3D submodel). The static-surface sublimation, which is the main contributor to the total ablation, is expected to be largely controlled by the wind speed and near-surface atmospheric vapor pressure fields through the energy balance equation (EnBal submodel)..

The activation of the blowing snow sublimation does not change the total sublimation rate averaged over the whole domain and the whole simulation period. Indeed, in both configurations, the model simulates very high sublimation rates, (71\% to $73 \%$ of the total ablation), which is in agreement with previous estimates [8]. Such sublimation rates are much higher than what has been generally reported from model applications in other mountainous regions $[56,57,58,23]$. However, the contribution of blowing snow sublimation to the snow mass balance is similar to [57] (also $18 \%$ of snow ablation). The effects of blowing snow sublimation are strongly variable in space as 
illustrated by [58]. Hence, blowing snow sublimation is responsible for the modification of the main snow patterns across the domain, leading to a better representation of the snow cover area as observed by MODIS. The blowing snow sublimation is highest in the high-altitude region, because the wind speeds are also highest (Fig. 5). The blowing snow sublimation is also higher on glacierized areas than non-glacierized areas (Fig. 13), but this difference is only the result of a strong drifting event on September-02 (Fig. 14). On this day, the wind transport is much larger on the glaciers, which explains why the blowing snow sublimation is also very high. The blowing snow sublimation also modifies the temporal distribution of the snow mass balance, leading to a lower runoff in September and October because the snowpack is more depleted when the main snowmelt season starts (Fig. 3). Similar results were reported in a semi-arid mountain catchment [25] (see Introduction).

Wind transport has a lower effect on the overall snow mass balance. This is partly due to the model resolution, which does not enable to model the redistribution of snow at scales lower than $90 \mathrm{~m}$. For smaller grid increment, the wind transport is expected to be greater [31]. Another possible reason for the low rates of snow transport is the absence of the preferential snow deposition process in the model [17]. It has been shown that preferential deposition of snow during precipitation events contributes to a large fraction of the redistributed snow at the ridges scale in the Swiss Alps [53]. Yet, the simulated snow transport pattern (Fig. 5) matches well the string of small cornice glaciers, which are know to form because of drift accumulation behind ridges, but do not give a conclusive answer over the largest glaciers. However, Fig 13 indicates that a slight gain of snow mass due to wind trans- 
port occurred from May to September on the glaciers, while the non-glacier areas experienced significant losses. This gain was lost in September due to a strong wind event which eroded away most of the accumulated snow. Later, the wind transport becomes negative over the glaciers because most remaining snow patches from the surrounding slopes are too far from the glaciers to provide them snow, hence, only erosion remains on the glaciers (erosion also occurred before in some parts of the glaciers, but was hidden due to the larger deposition from outside). This snow drift event might be overestimated by the model in its current configuration, since we used a constant wind friction threshold for snow transport, while (i) the snowpack consolidates with time and (ii) rising temperatures during spring should increases the minimum wind shear stress required to initiate snow transport. Therefore, the evolution of the wind friction threshold should be considered for future studies.

A simple test was performed to assess the sensitivity of the model to the uncertainty on the relative humidity. We have run two additional simulations with + and - the prediction error on the relative humidity from the crossvalidation exercise i.e. the root mean square error (within the limits 100\% $1 \%)$. The RMSE computed from all the available data is $9.8 \%$. The relative difference between both simulations is $14 \%$ on the total sublimation, $11 \%$ on the static-surface sublimation, $20 \%$ on the blowing snow sublimation. The effect is not strong enough to modify the shape of the monthly water budget described in Sect. 4.2.1. However, this test indicates that the uncertainty on the air humidity forcing may contribute to a significant part of the model error. 


\section{Conclusion}

We have investigated the effects of wind on the snow cover in the highaltitude semi-arid Andes using a distributed snow model. The model suggests that the blowing snow sublimation strongly affects the snow mass balance in the highest areas, where glacier are found. The results also tend to confirm the hypothesis that snow is transported onto the glacier from the surrounding ridges. This process reduces the snow mass loss over the snow season in combination with the shading effect by topography. In these conditions, snow transport may be a key "recharge" mechanism for glaciers, as it means that when snowfall is low in the area, glaciers would still receive preferential accumulation of drifting snow (similar insights can be found in [59]). This additional snow may also be critical to reduce the glaciers melt during the dry years by decreasing the glacier albedo. However, the model in its current setup suffers from several limitations, which are related to (i) the input data (lack of reliable precipitation measurements, low resolution digital elevation model), (ii) the characteristics of the study area (complex terrain leading to complex wind fields), (iii) the model parameters (terrain-based parameters and wind friction threshold) and (iv) the complexity of the physical processes involved in the wind-snow interactions (preferential deposition of falling snow is not represented). We believe that these specific issues should be addressed to further understand the hydrological balance of the semi-arid Andes, where the snow and the glacier represent critical water resources. 
Table 1: Snowmodel parameters

\begin{tabular}{lll}
\hline Parameter & Value & unit \\
\hline Curvature length scale & 500 & $\mathrm{~m}$ \\
Slope weight & 0.58 & - \\
Curvature weight & 0.42 & - \\
Threshold surface shear velocity & 0.25 & $\mathrm{~m} / \mathrm{s}$ \\
SnowTran-3D snow density & 250 & $\mathrm{~kg} / \mathrm{m}^{3}$ \\
Melting snowcover albedo & 0.6 & - \\
Dry snow albedo & 0.8 & - \\
Glacier surface albedo & 0.4 & - \\
\hline
\end{tabular}


Table 2: List of automatic weather stations and available hourly data, which were used to run SnowModel. TA: air temperature, RH: air humidity, SD: snow depth, WS: wind speed, WD, wind direction, SI: incoming shortwave radiation, LI: incoming longwave radiation. For the wind speed and direction, the measurement heights $(\mathrm{m})$ are indicated in subscript. If there are data gaps, the percentage of missing values is given in parenthesis. The stations located on glaciers are in italics.

\begin{tabular}{|c|c|c|}
\hline Station name & $\begin{array}{l}\text { Altitude } \\
\text { (m a.s.l.) }\end{array}$ & Variables \\
\hline El Colorado & 2618 & $\mathrm{TA}, \mathrm{RH}, \mathrm{WS}_{2,10}, \mathrm{WD}_{2,10}, \mathrm{SI}$ \\
\hline Potrerillos & 3282 & TA, RH, SI \\
\hline Tres Quebradas & 3583 & $\mathrm{TA}(15 \%), \mathrm{RH}(15 \%), \mathrm{SD}, \mathrm{WS}_{2,10}(13 \%), \mathrm{WD}_{2,10}(13 \%), \mathrm{SI}$ \\
\hline Campamento & 3717 & $\mathrm{TA}, \mathrm{RH}$ \\
\hline El Toro & 3735 & $\mathrm{TA}, \mathrm{RH}, \mathrm{SD}, \mathrm{WS}_{2,10}(1 \%), \mathrm{SI}$ \\
\hline La Olla & 3976 & $\mathrm{TA}, \mathrm{RH}, \mathrm{SD}, \mathrm{WS}_{2,10}, \mathrm{WD}_{2,10}$ \\
\hline Frontera & 4933 & $\mathrm{TA}, \mathrm{RH}, \mathrm{WS}_{2,10}(43 \%), \mathrm{WD}_{2,10}(43 \%), \mathrm{SI}$ \\
\hline Ortigas & 5209 & $\mathrm{TA}, \mathrm{RH}, \mathrm{SD}$ \\
\hline Toro 1 & 5226 & $\mathrm{TA}, \mathrm{SD}, \mathrm{WS}_{4,6}(1 \%), \mathrm{WD}_{4,6}, \mathrm{SI}(75 \%), \mathrm{LI}(75 \%)$ \\
\hline La Cumbre & 5292 & $\mathrm{TA}, \mathrm{RH}, \mathrm{WS}_{3,6}(13 \%), \mathrm{WD}_{3,6}$ \\
\hline Guanaco & 5317 & $\mathrm{TA}, \mathrm{RH}, \mathrm{SD}, \mathrm{WS}_{6}(75 \%), \mathrm{WD}_{6}(75 \%), \mathrm{SI}(75 \%), \mathrm{LI}(75 \%)$ \\
\hline
\end{tabular}


Table 3: Precipitation generated by MicroMet (cumulated by precipitation event)

\begin{tabular}{ll}
\hline date & Precipitation (mm w.e.) \\
\hline $27-28 / 05 / 2008$ & 48 \\
$18-19 / 06 / 2008$ & 67 \\
$26 / 06 / 2008$ & 7 \\
$21 / 07 / 2008$ & 16 \\
$01 / 08 / 2008$ & 9 \\
$15-16-17 / 08 / 2008$ & 36 \\
\hline
\end{tabular}

Table 4: Monthly lapse rates of air temperature $\left(\Gamma_{a}\right)$ and dewpoint temperature $\left(\Gamma_{d}\right)$. The lapse rates in the study area were determined for air temperature $\left(T_{a}\right)$ and dewpoint temperature $\left(T_{a}\right)$ by linear regression between the observations and the elevations of the meteorological stations. The square of the correlation coefficient is indicated for every variable and month.

\begin{tabular}{lclllll}
\hline & \multicolumn{3}{c}{ MicroMet default } & \multicolumn{2}{c}{ Study area } & \multicolumn{2}{c}{$R^{2}$} \\
\hline Month & $\Gamma_{a}$ & $\Gamma_{d}$ & $\Gamma_{a}$ & $\Gamma_{d}$ & $T_{a}$ & $T_{d}$ \\
\hline 5 & -5.5 & -4.9 & -7.9 & -3.5 & 0.996 & 0.784 \\
6 & -4.7 & -4.9 & -8.0 & -3.2 & 0.984 & 0.549 \\
7 & -4.4 & -5.0 & -8.2 & -3.6 & 0.976 & 0.775 \\
8 & -5.9 & -5.1 & -8.4 & -3.9 & 0.982 & 0.680 \\
9 & -7.1 & -4.9 & -8.6 & -3.9 & 0.990 & 0.629 \\
10 & -7.8 & -4.7 & -8.7 & -3.9 & 0.996 & 0.739 \\
11 & -8.1 & -4.6 & -8.4 & -4.8 & 0.995 & 0.917 \\
\hline
\end{tabular}


Table 5: Results of MicroMet cross-validation (coefficient of determination and bias calculated on hourly data) for each station (air temperature and humidity lapse rates monthly values were set from local observations). For the wind direction, only the bias was computed.

\begin{tabular}{lllllllllllll}
\hline Station & \multicolumn{2}{c}{$\mathrm{TA}\left({ }^{\circ} \mathrm{C}\right)$} & \multicolumn{2}{c}{$\mathrm{RH}(\%)$} & \multicolumn{2}{l}{$\mathrm{WS}(\mathrm{m} / \mathrm{s})$} & $\mathrm{WD}\left({ }^{\circ}\right)$ & $\mathrm{SI}\left(\mathrm{W} / \mathrm{m}^{2}\right)$ & \multicolumn{2}{c}{$\mathrm{LI}\left(\mathrm{W} / \mathrm{m}^{2}\right)$} \\
\hline & $R^{2}$ & $B$ & $R^{2}$ & $B$ & $R^{2}$ & $B$ & $B$ & $R^{2}$ & $B$ & $R^{2}$ & $B$ \\
\hline Guanaco & 0.98 & -0.20 & 0.92 & 2.14 & 0.24 & -4.39 & -1.70 & 0.99 & -49.68 & 0.95 & 6.50 \\
Ortigas & 0.95 & -0.75 & 0.80 & 7.35 & - & - & - & - & - & - & - \\
El Toro & 0.95 & -1.33 & 0.90 & 3.54 & 0.03 & -1.01 & - & 0.97 & 21.97 & - & - \\
Tres Que. & 0.91 & -0.17 & 0.87 & 2.06 & 0.25 & -0.90 & -79.25 & 0.95 & 23.21 & - & - \\
Portrerillo & 0.83 & 0.46 & 0.58 & -6.44 & - & - & - & 0.99 & -0.74 & - & - \\
Frontera & 0.96 & -0.41 & 0.81 & -2.93 & 0.31 & -1.24 & -41.33 & 0.92 & -26.27 & - & - \\
La Olla & 0.95 & 0.97 & 0.86 & -5.18 & 0.13 & 0.53 & 16.46 & 0.97 & 5.59 & - & - \\
La Cumbre & 0.98 & 0.06 & 0.93 & 2.41 & 0.36 & -3.65 & 12.37 & - & - & - & - \\
Toro 1 & 0.97 & -0.03 & - & - & 0.25 & -1.89 & 28.14 & 0.97 & -37.37 & 0.96 & -6.68 \\
\hline
\end{tabular}




\section{References}

[1] L. Lliboutry, Glaciers of the Dry Andes, in: Satellite Image Atlas of Glaciers of the World: South America, United State Geological Survey Professional Paper 1386-I, 1998.

[2] L. Nicholson, J. Marin, D. Lopez, A. Rabatel, F. Bown, A. Rivera, Glacier inventory of the upper Huasco valley, Norte Chico, Chile: glacier characteristics, glacier change and comparison with central Chile, Annals of Glaciology 50 (2010) 111-118.

[3] V. Favier, M. Falvey, A. Rabatel, E. Praderio, D. López, Interpreting discrepancies between discharge and precipitation in high-altitude area of Chile's Norte Chico region (26-32 S), Water Resources Research 45 (2009) W02424.

[4] J. Oyarzún, R. Oyarzún, Sustainable development threats, inter-sector conflicts and environmental policy requirements in the arid, mining rich, northern chile territory, Sustainable Development 19 (2011) 263-274.

[5] S. Fields, The Price of Gold in Chile, Environmental Health Perspectives 114 (2006) A536.

[6] P. Ginot, C. Kull, U. Schotterer, M. Schwikowski, H. W. Gäggeler, Glacier mass balance reconstruction by sublimation induced enrichment of chemical species on Cerro Tapado (Chilean Andes), Climate of the Past 2 (2006) 21-30.

[7] P. Ginot, C. Kull, M. Schwikowski, U. Schotterer, H. Gäggeler, Effects of postdepositional processes on snow composition of a subtropical glacier 
(Cerro Tapado, Chilean Andes), Journal of Geophysical Research 106 (2001) 32375-32.

[8] S. Gascoin, C. Kinnard, R. Ponce, S. Lhermitte, S. MacDonell, A. Rabatel, Glacier contribution to streamflow in two headwaters of the Huasco River, Dry Andes of Chile, The Cryosphere 5 (2011) 1099-1113.

[9] A. Rabatel, H. Castebrunet, V. Favier, L. Nicholson, C. Kinnard, Glacier changes in the pascua-lama region, Chilean Andes (29 S): recent mass balance and 50 yr surface area variations, The Cryosphere 5 (2011) $1029-1041$.

[10] M. Kuhn, Redistribution of snow and glacier mass balance from a hydrometeorological model, Journal of Hydrology 282 (2003) 95-103.

[11] H. Machguth, O. Eisen, F. Paul, M. Hoelzle, Strong spatial variability of snow accumulation observed with helicopter-borne GPR on two adjacent Alpine glaciers, Geophysical Research Letters 33 (2006) 13503.

[12] R. Mott, F. Faure, M. Lehning, H. Lowe, B. Hynek, G. Michlmayer, A. Prokop, W. Schoner, Simulation of seasonal snow-cover distribution for glacierized sites on Sonnblick, Austria, with the Alpine3D model, Annals of Glaciology 49 (2008) 155-160.

[13] M. Bernhardt, G. Liston, U. Strasser, G. Zängl, K. Schulz, High resolution modelling of snow transport in complex terrain using downscaled MM5 wind fields, The Cryosphere 4 (2010) 99-113.

[14] R. Dadic, R. Mott, M. Lehning, P. Burlando, Wind influence on snow 
depth distribution and accumulation over glaciers, Journal of Geophysical Research 115 (2010) F01012.

[15] L. Carturan, F. Cazorzi, G. D. Fontana, Distributed mass-balance modelling on two neighbouring glaciers in Ortles-Cevedale, Italy, from 2004 to 2009, Journal of Glaciology 58 (2012) 467-486.

[16] H. Purdie, B. Anderson, W. Lawson, A. Mackintosh, Controls on spatial variability in snow accumulation on glaciers in the Southern Alps, New Zealand; as revealed by crevasse stratigraphy, Hydrological Processes 25 (2011) 54-63.

[17] M. Lehning, H. Löwe, M. Ryser, N. Raderschall, Inhomogeneous precipitation distribution and snow transport in steep terrain, Water Resources Research 44 (2008) W07404.

[18] K. Fujita, K. Hiyama, H. Iida, Y. Ageta, Self-regulated fluctuations in the ablation of a snow patch over four decades, Water Resources Research 46 (2010) W11541.

[19] R. Mott, C. Gromke, T. Grünewald, M. Lehning, Relative importance of advective heat transport and boundary layer decoupling in the melt dynamics of a patchy snow cover, Advances in Water Resources in press (2012)-

[20] R. Dadic, R. Mott, M. Lehning, M. Carenzo, B. Anderson, A. Mackintosh, Sensitivity of turbulent fluxes to wind speed over snow surfaces in different climatic settings, Advances in Water Resources (2012)-. 
[21] G. Liston, M. Sturm, A snow-transport model for complex terrain, Journal of Glaciology 44 (1998) 498-516.

[22] J. Pomeroy, R. Essery, Turbulent fluxes during blowing snow: field tests of model sublimation predictions, Hydrological Processes 13 (1999) $2963-2975$.

[23] C. Groot Zwaaftink, H. Löwe, R. Mott, M. Bavay, M. Lehning, Drifting snow sublimation: A high-resolution 3-D model with temperature and moisture feedbacks, Journal of Geophysical Research 116 (2011) D16107.

[24] D. Marks, A. Winstral, Comparison of snow deposition, the snow cover energy balance, and snowmelt at two sites in a semiarid mountain basin, Journal of Hydrometeorology 2 (2001) 213-227.

[25] A. Winstral, D. Marks, Simulating wind fields and snow redistribution using terrain-based parameters to model snow accumulation and melt over a semi-arid mountain catchment, Hydrological Processes 16 (2002) $3585-3603$.

[26] G. Liston, K. Elder, A distributed snow-evolution modeling system (SnowModel), Journal of Hydrometeorology 7 (2006) 1259-1276.

[27] B. Ryan, A mathematical model for diagnosis and prediction of surface winds in mountainous terrain., Journal of Applied Meteorology 16 (1977) 571-584.

[28] J. Corripio, R. Purves, A. Rivera, Modeling climate-change impacts on mountain glaciers and water resources in the Central Dry Andes, in: 
Darkening Peaks: Glacier Retreat, Science and Society, University of California Press, USA, 2007, pp. 126-135.

[29] M. D. Betterton, Theory of structure formation in snowfields motivated by penitentes, suncups, and dirt cones, Phys. Rev. E 63 (2001) 056129.

[30] Comisión Regional del Medio Ambiente, Región de Atacama, Gobierno de Chile, Resolución rca 024, 2006.

[31] G. Liston, R. Haehnel, M. Sturm, C. Hiemstra, S. Berezovskaya, R. Tabler, Simulating complex snow distributions in windy environments using SnowTran-3D, Journal of Glaciology 53 (2007) 241-256.

[32] E. Greene, G. Liston, R. Pielke Sr, Simulation of above treeline snowdrift formation using a numerical snow-transport model, Cold Regions Science and Technology 30 (1999) 135-144.

[33] G. Liston, M. Sturm, Winter precipitation patterns in arctic alaska determined from a blowing-snow model and snow-depth observations, Journal of hydrometeorology 3 (2002) 646-659.

[34] G. Liston, K. Elder, A meteorological distribution system for highresolution terrestrial modeling (micromet), Journal of Hydrometeorology 7 (2006) 217-234.

[35] G. Liston, D. Hall, Sensitivity of lake freeze-up and break-up to climate change: a physically based modeling study, Annals of Glaciology 21 (1995) 387-393. 
[36] G. Liston, Local advection of momentum, heat, and moisture during the melt of patchy snow covers, Journal of Applied Meteorology 34 (1995) $1705-1715$.

[37] S. Barnes, A technique for maximizing details in numerical weather map analysis, J. Appl. Meteor 3 (1964) 396-409.

[38] C. Walcek, Cloud cover and its relationship to relative humidity during a springtime midlatitude cyclone, Monthly Weather Review 122 (1994) $1021-1035$.

[39] S. MacDonell, L. Nicholson, C. Kinnard, Parameterisation of incoming longwave radiation over glacier surfaces in the semiarid Andes of Chile, Theoretical and Applied Climatology (2012) 1-16.

[40] T. Farr, P. Rosen, E. Caro, R. Crippen, R. Duren, S. Hensley, M. Kobrick, M. Paller, E. Rodriguez, L. Roth, et al., The Shuttle Radar Topography Mission, Reviews of Geophysics 45 (2007).

[41] G. Liston, C. Hiemstra, A simple data assimilation system for complex snow distributions (SnowAssim), Journal of Hydrometeorology 9 (2008) 989-1004.

[42] E. Anderson, A point of energy and mass balance model of a snow cover, Technical Report, NOAA, 1976.

[43] R. Rogers, A Short Course in Cloud Physics, Pergamon Press, Elmsford (NY, USA), 1979. 
[44] A. Buck, New equations for computing vapor pressure and enhancement factor, Journal of Applied Meteorology 20 (1981) 1527-1532.

[45] R. Fleagle, J. Businger, An introduction to atmospheric physics, volume 25, Academic Press, 1980.

[46] P. Holland, R. Welsch, Robust regression using iteratively reweighted least-squares, Communications in Statistics-Theory and Methods 6 (1977) 813-827.

[47] G. Liston, Representing subgrid snow cover heterogeneities in regional and global models, Journal of Climate 17 (2004) 1381-1397.

[48] K. Andreadis, D. Lettenmaier, Assimilating remotely sensed snow observations into a macroscale hydrology model, Advances in Water Resources 29 (2006) 872-886.

[49] A. Klein, A. Barnett, Validation of daily MODIS snow cover maps of the Upper Rio Grande River Basin for the 2000-2001 snow year, Remote Sensing of Environment 86 (2003) 162-176.

[50] D. Hall, G. Riggs, V. Salomonson, N. DiGirolamo, K. Bayr, MODIS snow-cover products, Remote sensing of Environment 83 (2002) 181194.

[51] D. Hall, G. Riggs, Accuracy assessment of the MODIS snow products, Hydrological Processes 21 (2007) 1534-1547.

[52] J. Parajka, G. Blöschl, Spatio-temporal combination of MODIS imagespotential for snow cover mapping, Water Resour. Res 44 (2008) W03406. 
[53] R. Mott, M. Lehning, Meteorological modeling of very high-resolution wind fields and snow deposition for mountains, Journal of Hydrometeorology 11 (2010) 934-949.

[54] R. Mott, M. Schirmer, M. Bavay, T. Grünewald, M. Lehning, Understanding snow-transport processes shaping the mountain snow-cover, The Cryosphere 4 (2010) 545-559.

[55] R. Prasad, D. Tarboton, G. Liston, C. Luce, M. Seyfried, Testing a blowing snow model against distributed snow measurements at Upper Sheep Creek, Idaho, United States of America, Water Resources Research 37 (2001) 1341-1356.

[56] O. Schulz, C. de Jong, Snowmelt and sublimation: field experiments and modelling in the High Atlas Mountains of Morocco, Hydrology and Earth System Sciences 8 (2004) 1076-1089.

[57] M. K. MacDonald, J. W. Pomeroy, A. Pietroniro, On the importance of sublimation to an alpine snow mass balance in the Canadian Rocky Mountains, Hydrology and Earth System Sciences 14 (2010) 1401-1415.

[58] U. Strasser, M. Bernhardt, M. Weber, G. Liston, W. Mauser, Is snow sublimation important in the alpine water balance?, The Cryosphere 2 (2008) 53-66.

[59] M. Hoffman, A. Fountain, J. Achuff, 20th-century variations in area of cirque glaciers and glacierets, rocky mountain national park, rocky mountains, colorado, usa, Annals of Glaciology 46 (2007) 349-354. 


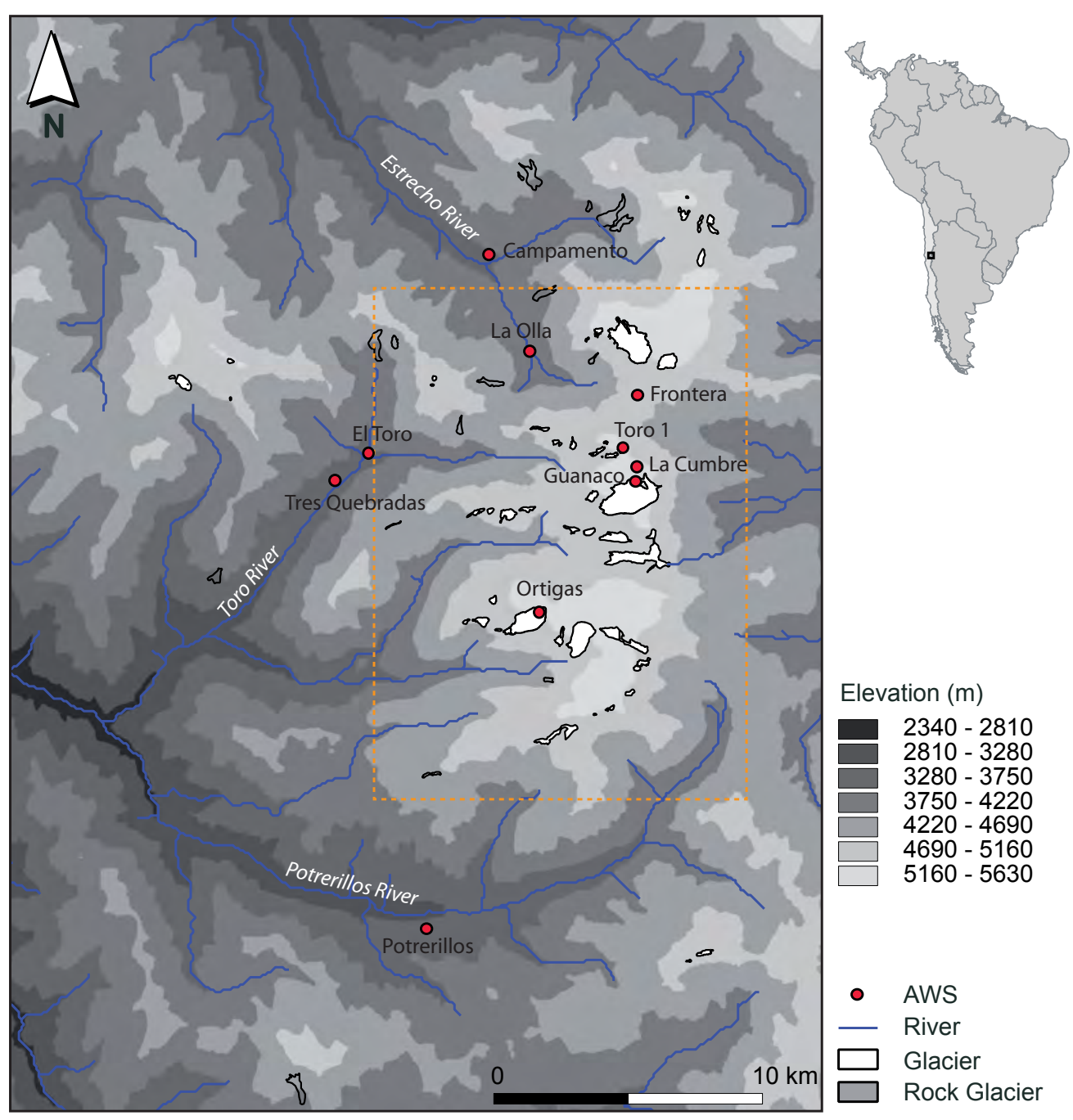

Figure 1: Map of the study area showing the location of the automatic weather stations (AWS). The map has the same extent as the computational grid. El Colorado AWS is not shown as it lies outside of the modeling grid (located $11 \mathrm{~km}$ west from western edge, at the same latitude of Campamento AWS). The rectangle in dotted orange line indicate the glacier area as used in Fig. 4. 

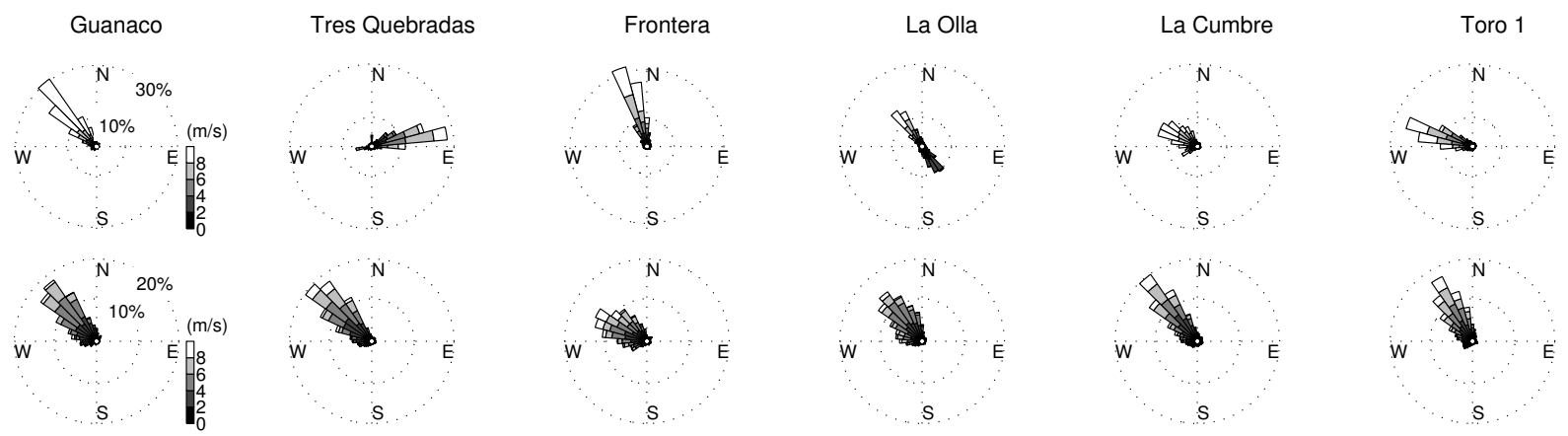

Figure 2: Wind roses between 1-May-2008 and 30-Nov-2008 for 6 weather stations. Top row: measurements, bottom row: MicroMet simulations.
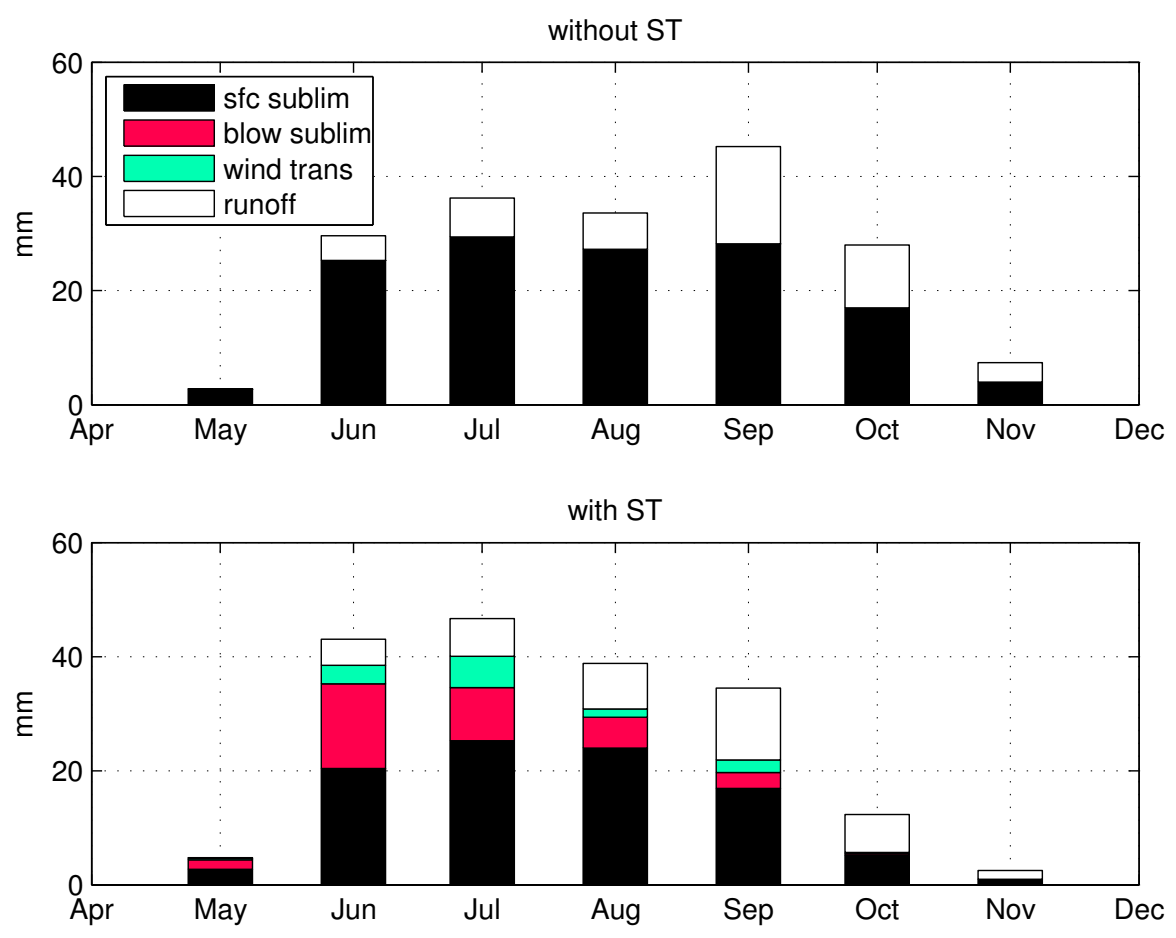

Figure 3: Comparison of model snow mass budgets without and with SnowTran (ST). Legend: sfc sublim: surface-static sublimation, blow sublim: sublimation of blowing snow, wind trans: wind transported snow, runoff. 

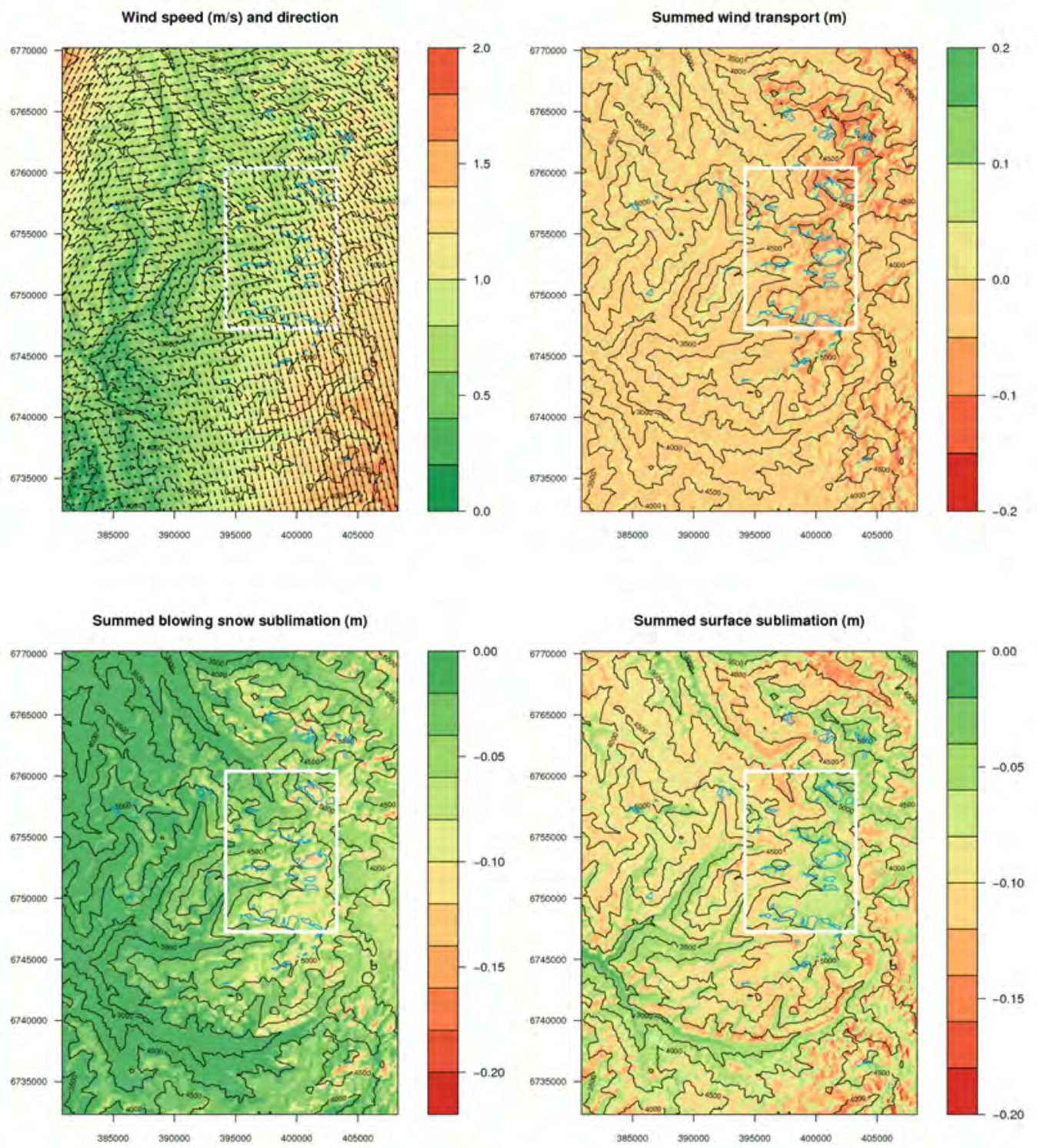

Figure 4: Maps of the model outputs over the full domain: mean wind field, total wind transported snow (saltation and suspension), sublimation of blowing snow and staticsurface sublimation (in $\mathrm{m}$ w.e., all fluxes are cumulated over the simulation period). The glacier contours are drawn in blue. The axes are the northing $(\mathrm{m})$ and easting $(\mathrm{m})$ the WGS-84 UTM 19S projection. 

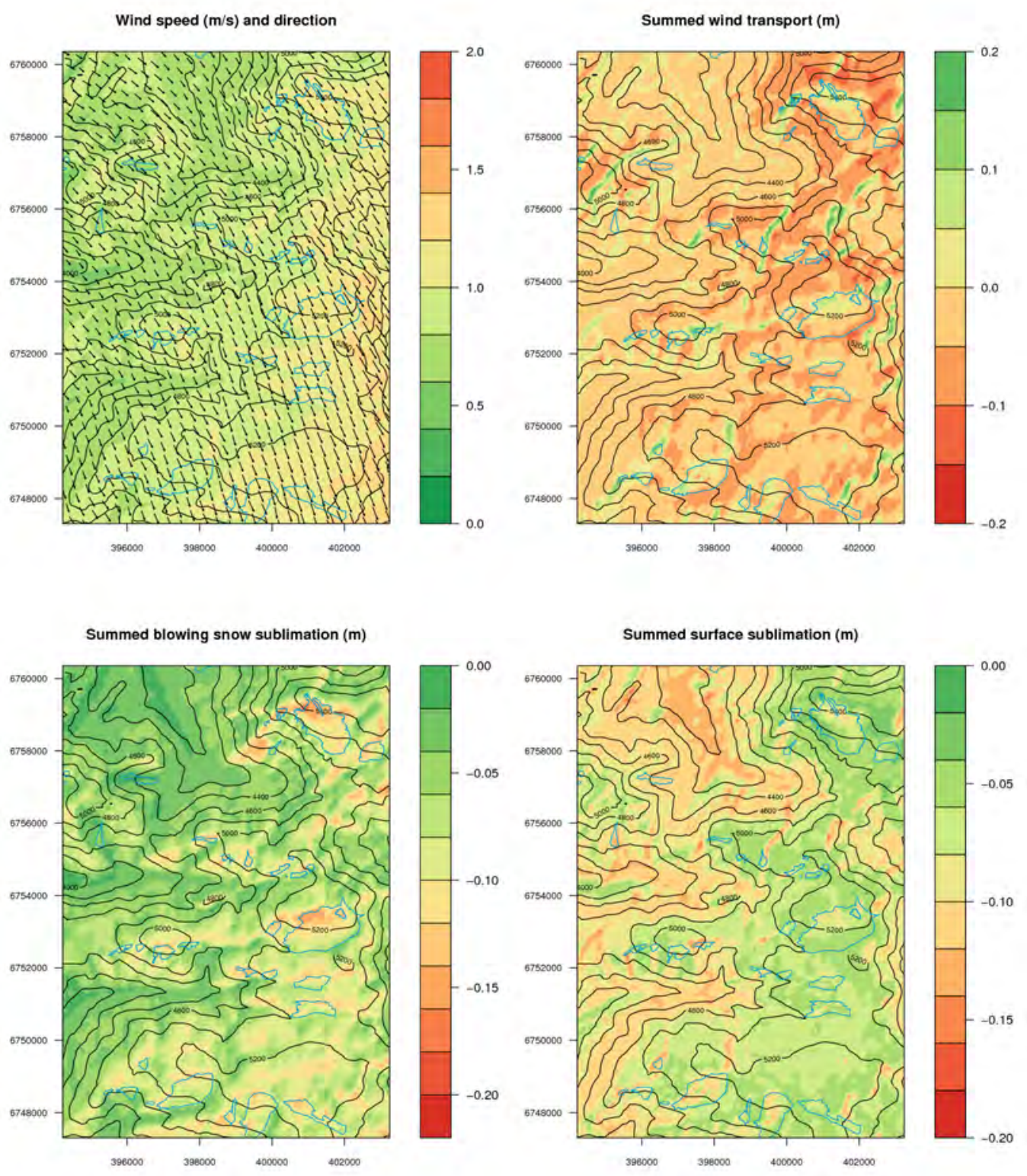

Figure 5: Same as Fig. 4 but zoomed over the glacier area. 

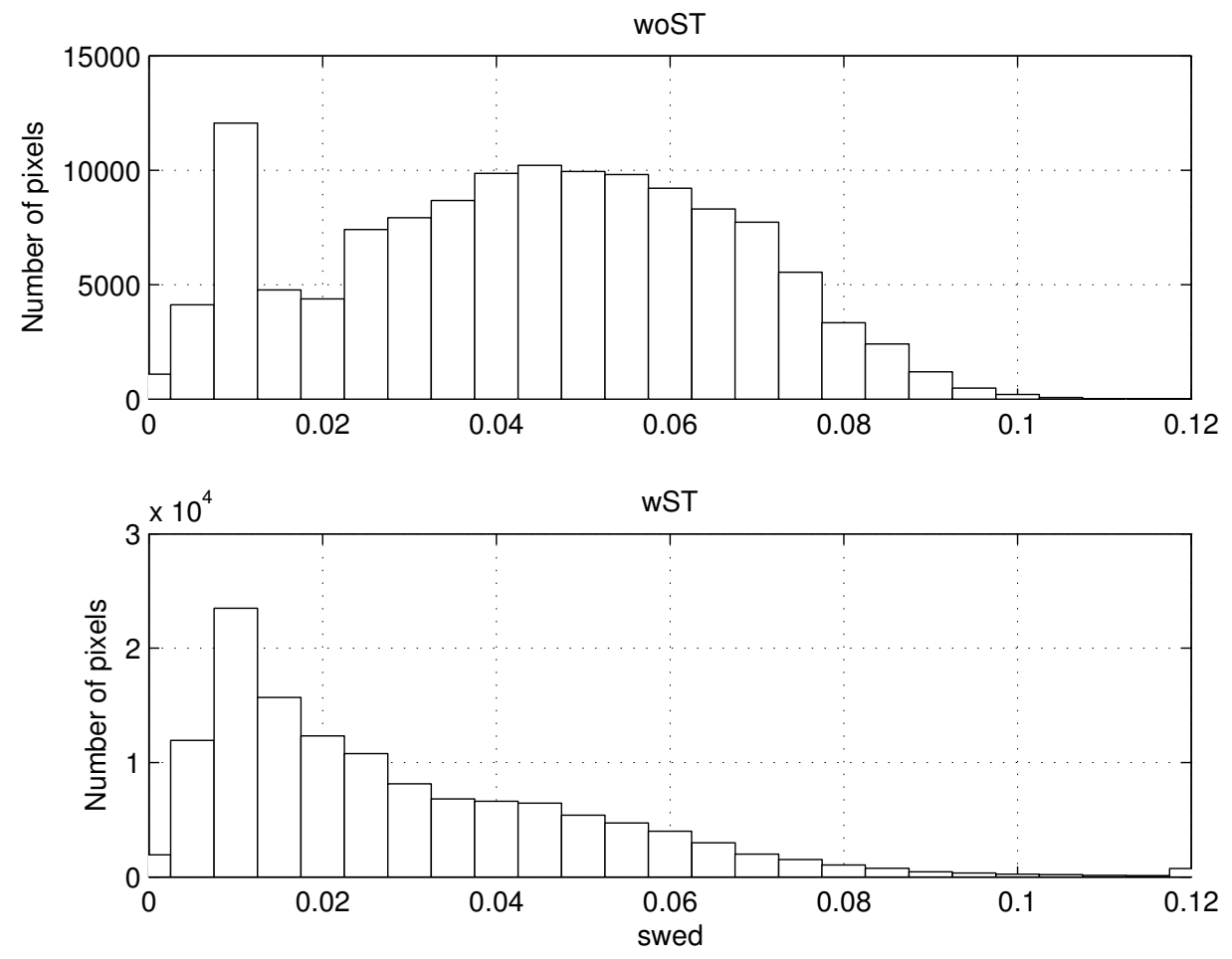

Figure 6: Distribution of the mean SWE depth (in m) calculated for each grid cell over the model run period (woST: without SnowTran, wST: with SnowTran). 

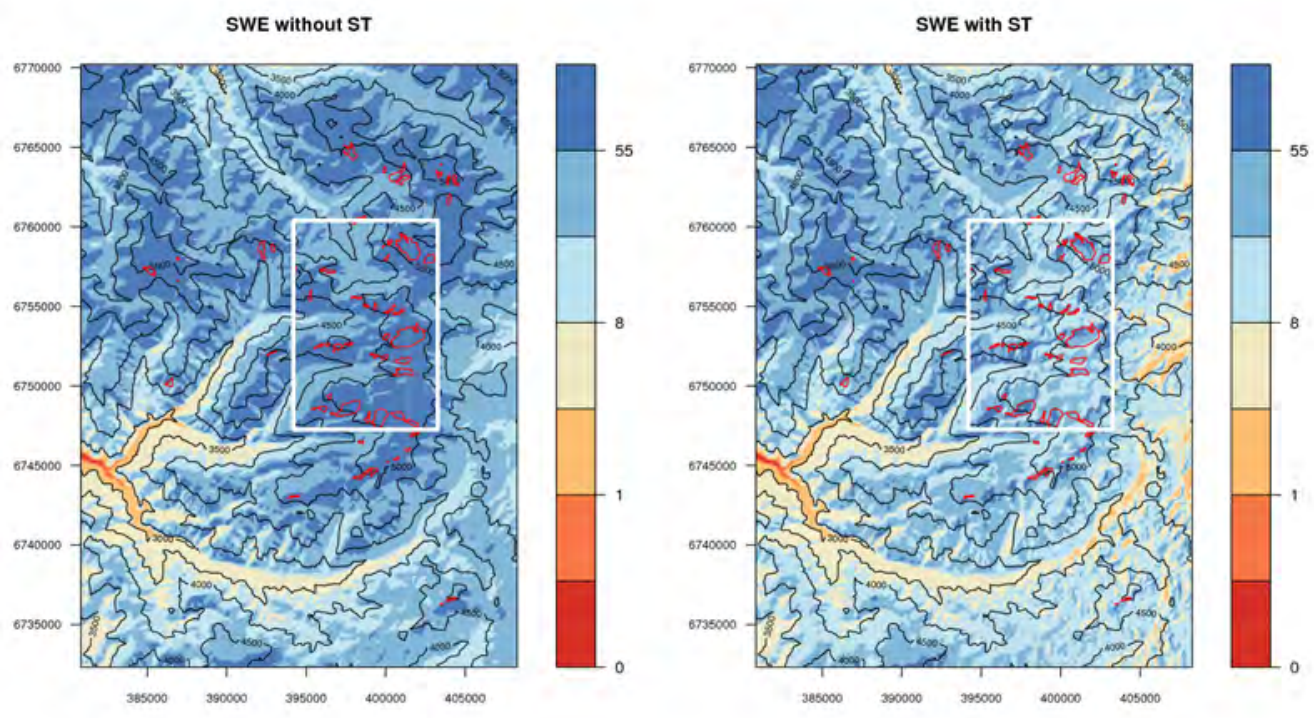

Figure 7: Maps of the mean simulated SWE for both model configurations (logarithmic scale in $\mathrm{mm}$ ). The glacier contours are drawn in red. 

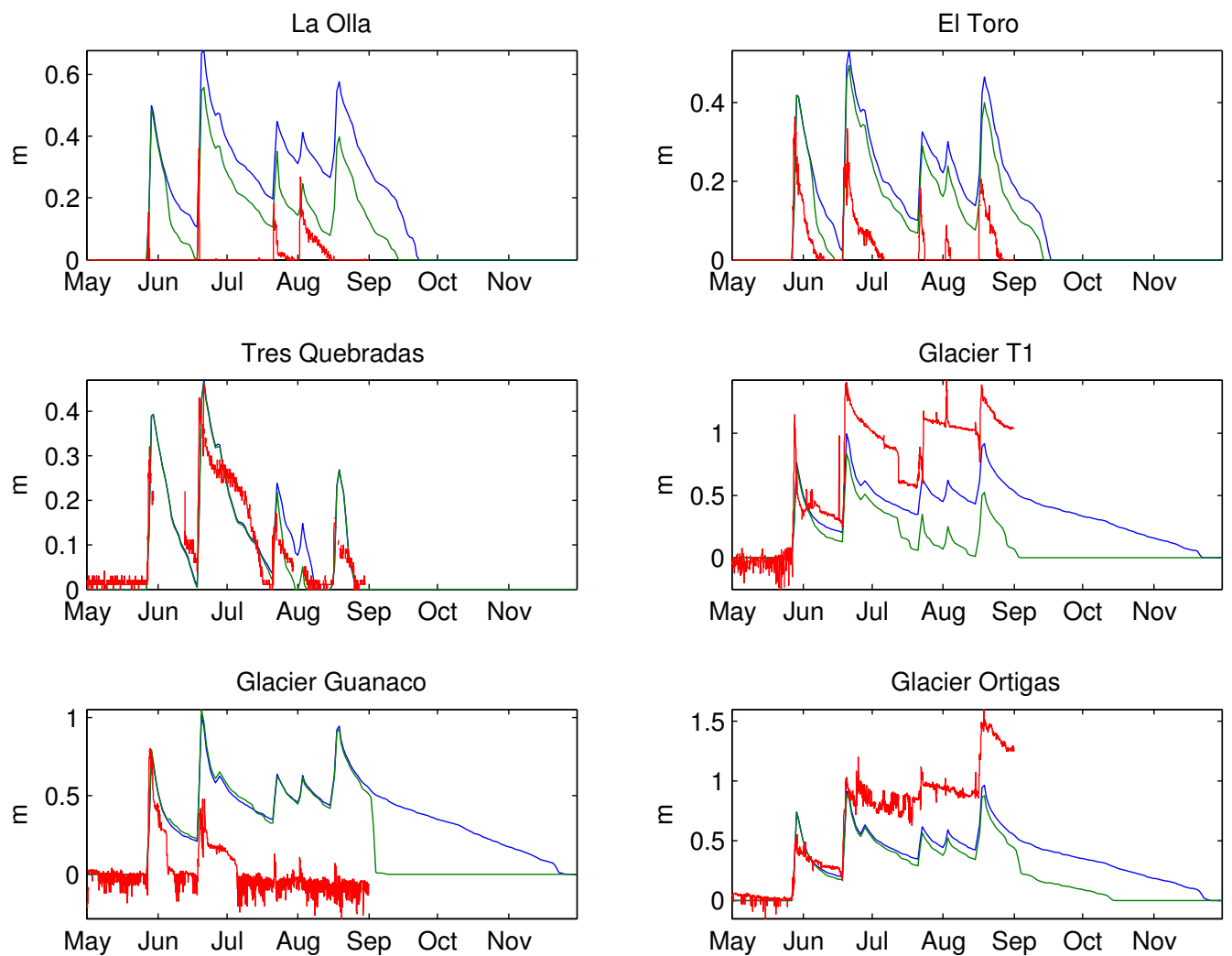

Figure 8: Simulated vs. observed snow depth at 6 stations. Legend: blue: SnowModel without SnowTran, green: with SnowTran, red: observations. 


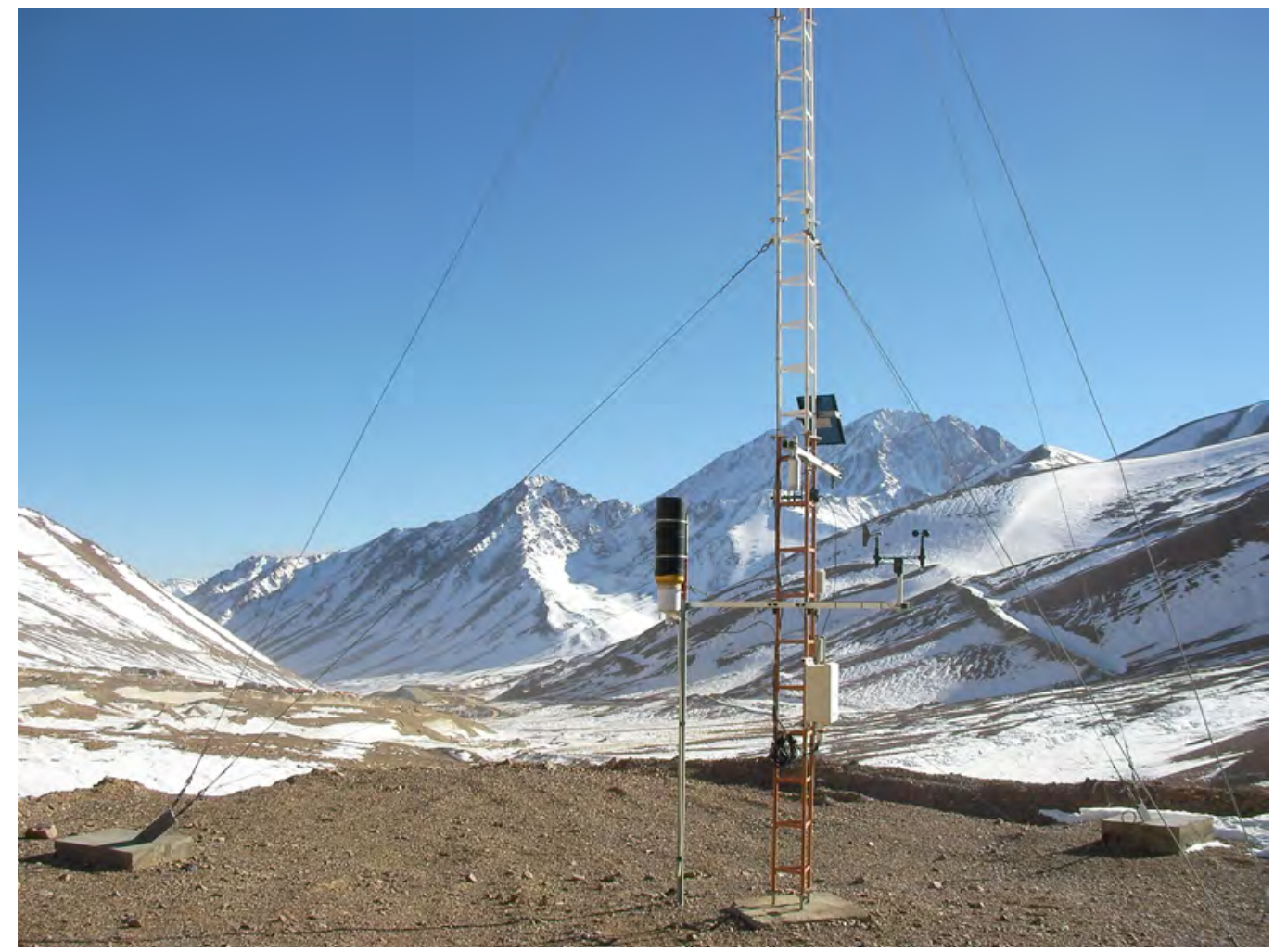

Figure 9: La Olla weather station (photograph taken on 21-7-2010) 


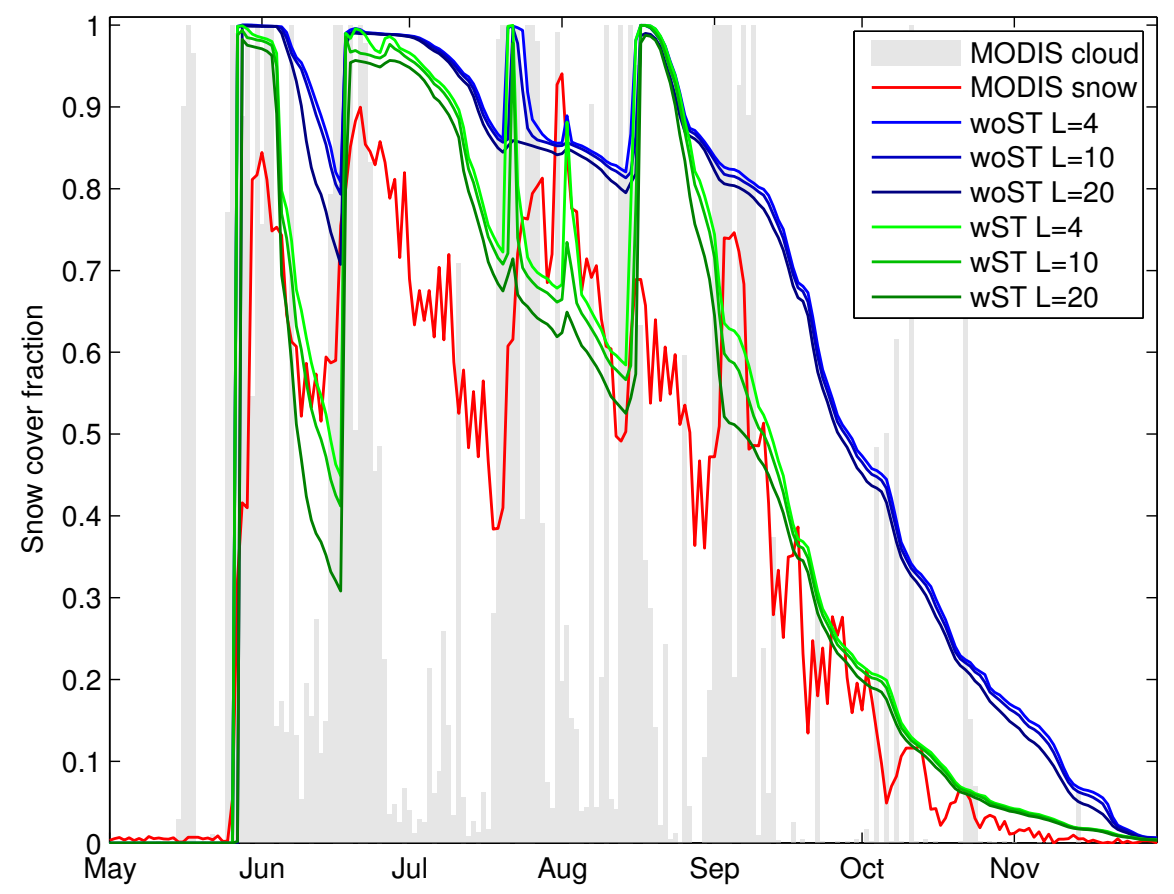

Figure 10: Snow coverage from SnowModel simulations and MOD10A1 (MODIS 500$\mathrm{m}$ daily snow cover product). The snow cover area was computed for both simulations (without ST and with ST) using three different SWE thresholds (L indicated in the legend in $\mathrm{mm}$, see Sect. 3.4). The fractional area of cloud cover is indicated in light gray. The total domain area is $1043 \mathrm{~km}^{2}$ (Fig. 1). 

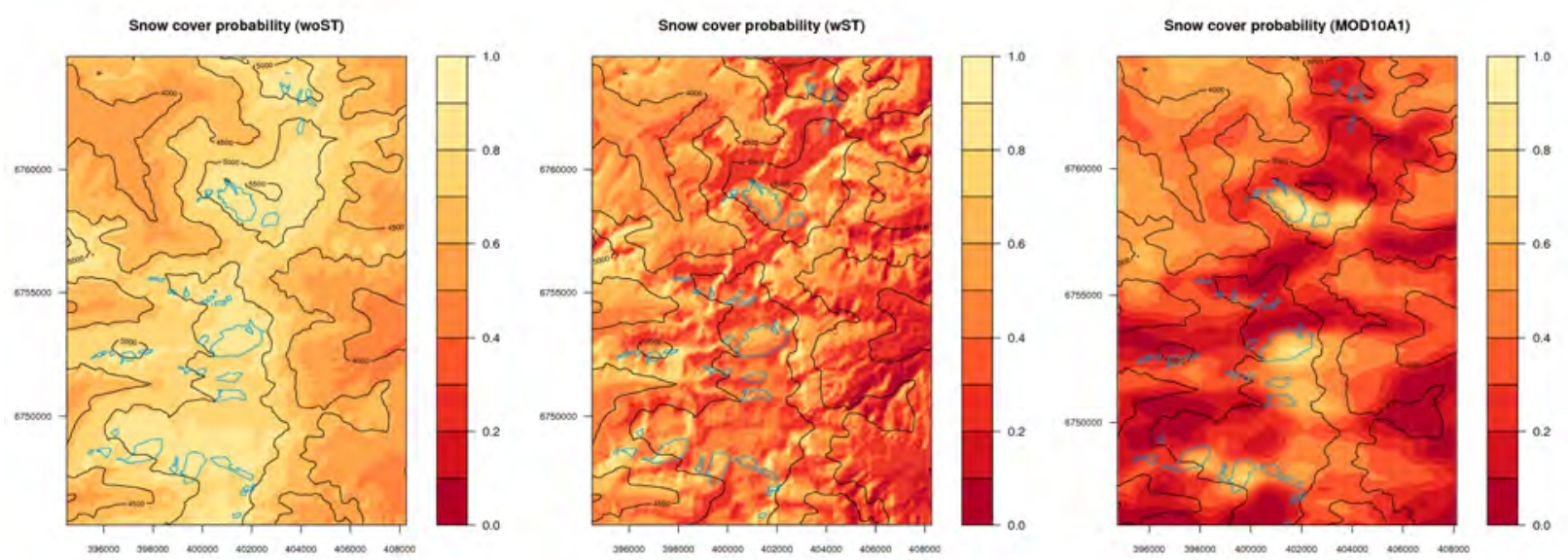

Figure 11: Simulated vs. observed snow cover probabilities over the simulation period in the glacier area. 

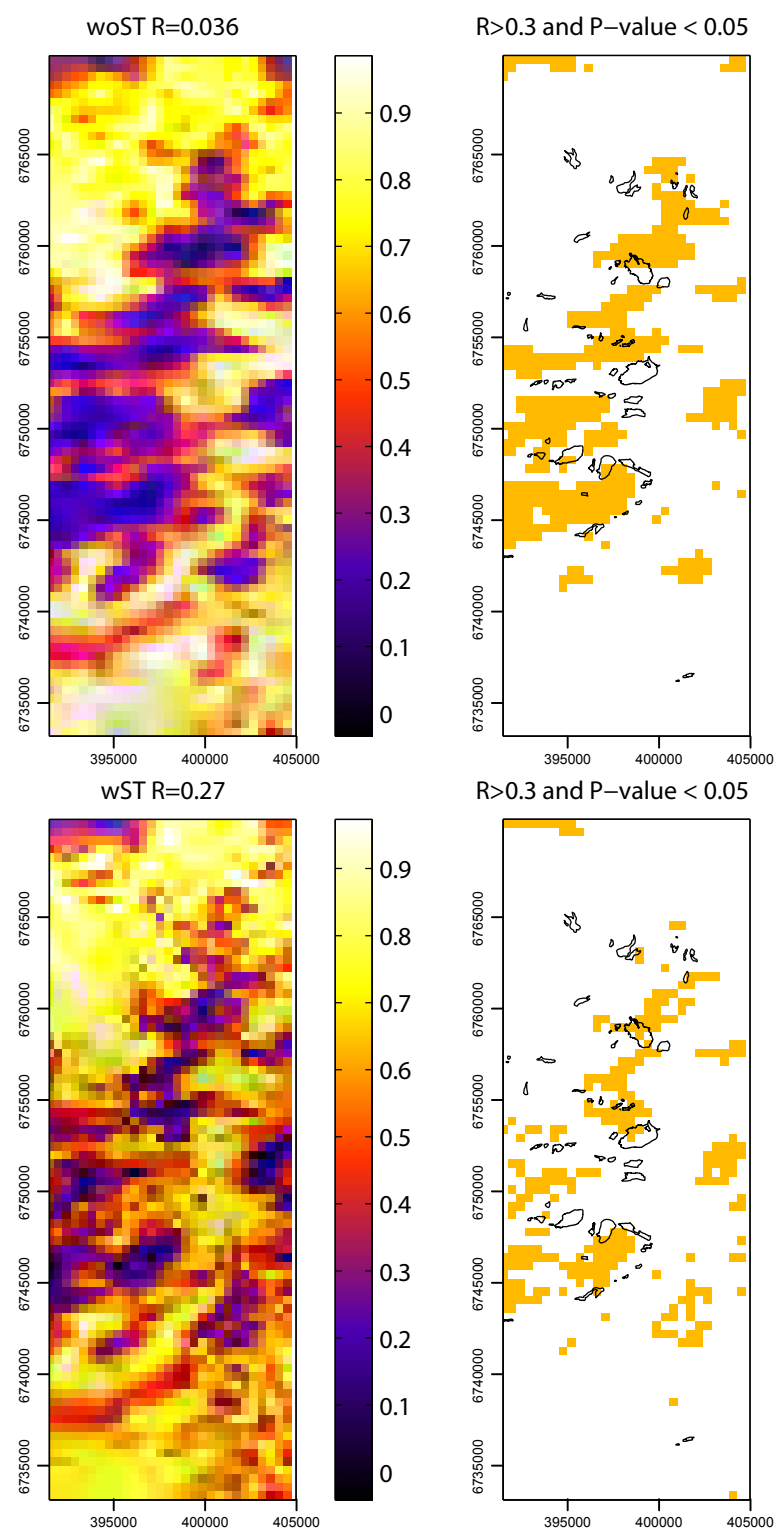

Figure 12: Left: Correlation maps between the simulated snow cover resampled to $500 \mathrm{~m}$ and MOD10A1 in the eastern part of the study area. The 2-D correlation coefficient $(R)$ is indicated for both runs (SnowModel without or with SnowTran). Right: the area in white has a correlation coefficient $R>0.3$ and a $P$-value $<0.05$ (probability of no correlation lower than $5 \%$ ). 

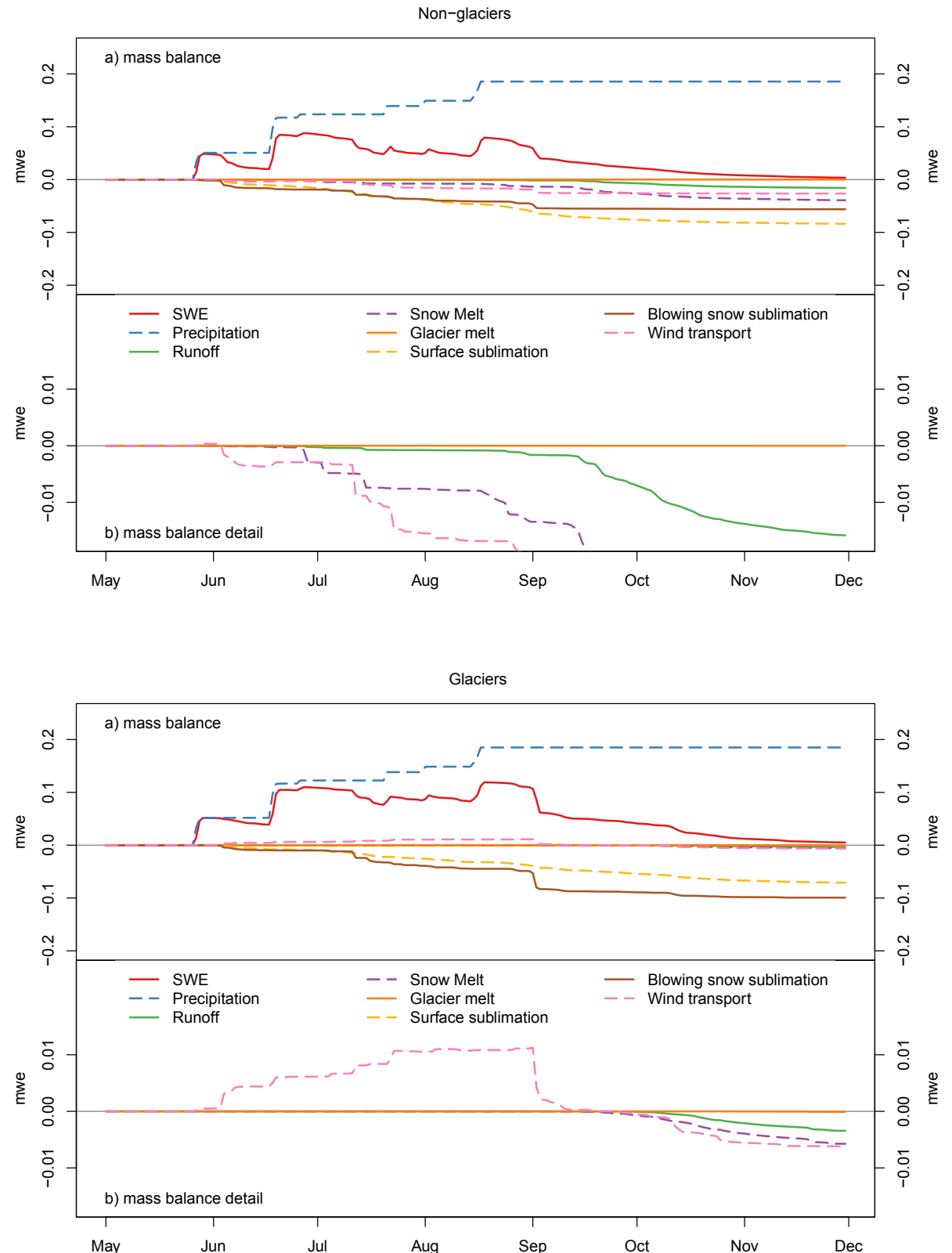

Figure 13: Snow mass balance components averaged over the glacierized area and the non-glacierized area above 4475 m a.s.l. (simulation with SnowTran-3D). 


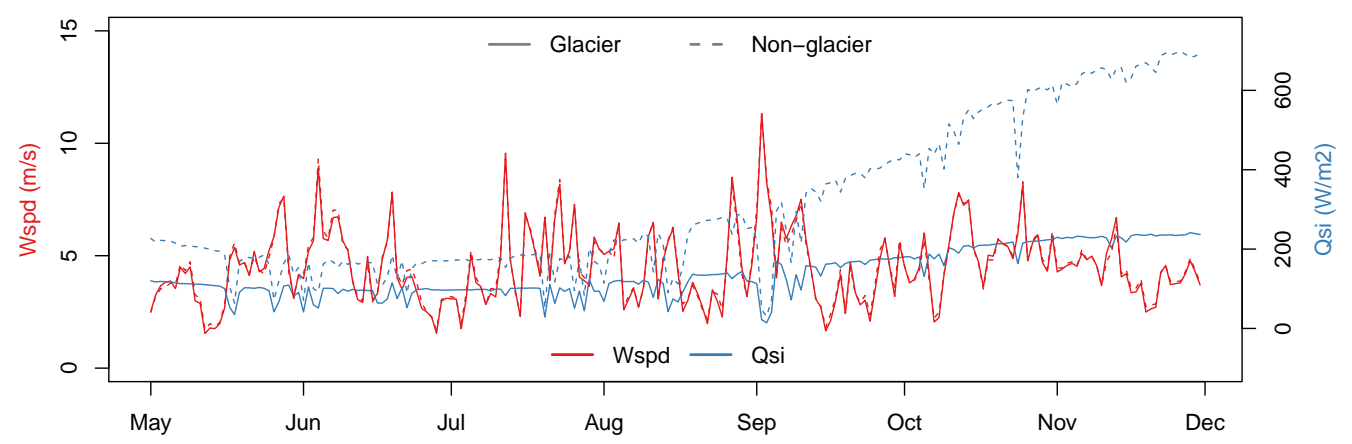

Figure 14: MicroMet simulated wind speed and incoming shortwave radiation averaged over glaciers (continuous line) and glacier-free areas above the lower glacier elevation (dashed line). 


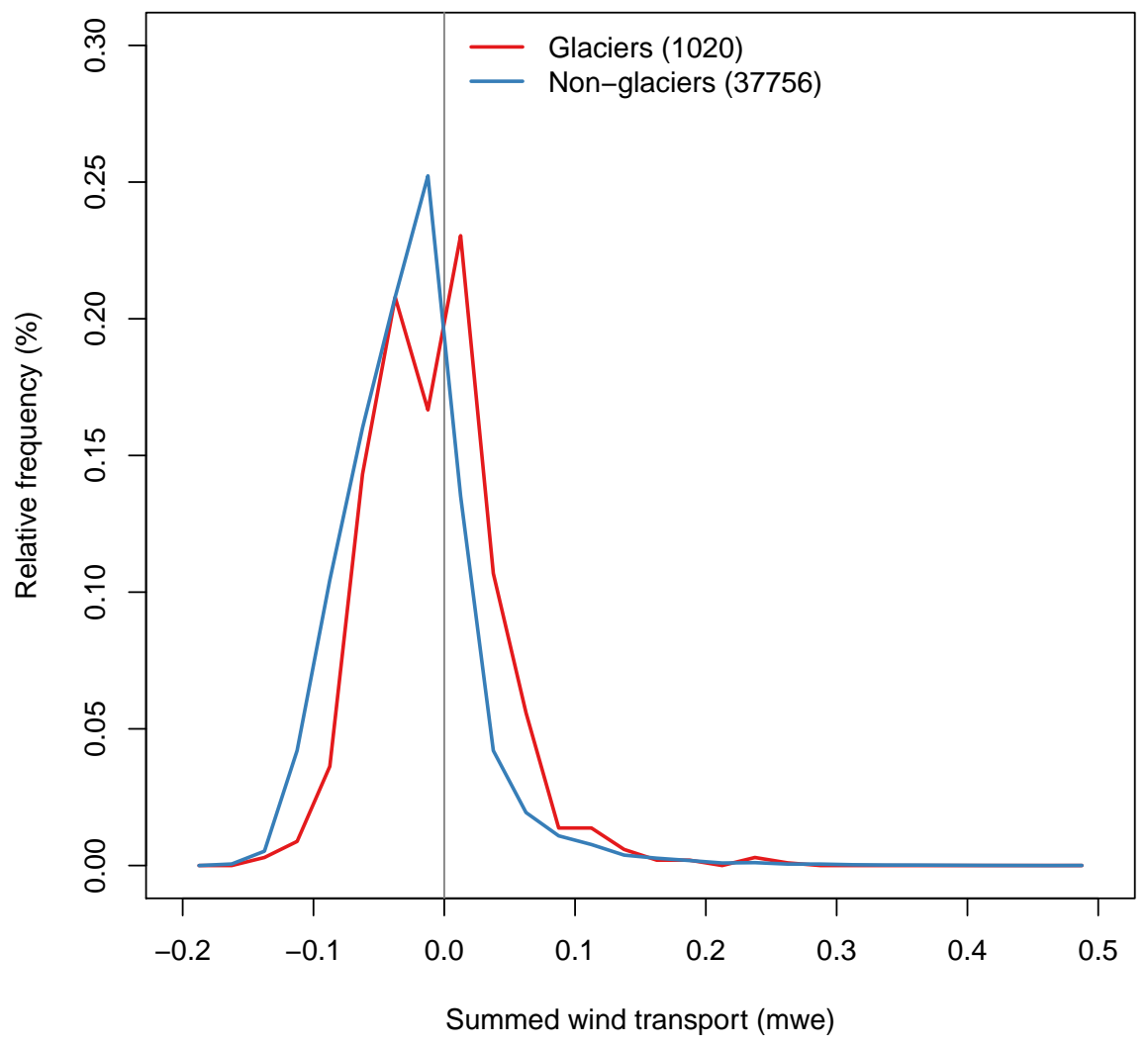

Figure 15: Frequency distribution of the transport rates simulated for the grid points located above $4475 \mathrm{~m}$ a.s.l. (frequencies calculated for $0.025 \mathrm{~m}$ w.e. bins). 